\title{
5. \\ JEWS AS A CHANGING PEOPLE OF THE TALMUD: AN AMERICAN EXPLORATION
}

Even as John Cotton used the traditional concept of the "Land of Promise" to justify the first Puritan settlement in New England on lands inhabited by New World Indians, other Protestants signaled a change in that New Testament "promise" by inventing the "Promised Land." In time, English settlers and their Anglo-American descendants associated themselves with the new phrase. It was a way to celebrate material achievement, exceptional spiritual election, and thus an association by which they could continue to conquer and rule the Indian as a primitive alien in his own land. Indeed, together with other white Christians who joined the American colonial and revolutionary enterprise they identified with what appeared to them to be a God-directed freshness. This "freshness" made their individual and collective lives in the United States as special as the New World itself. ${ }^{1}$ As individuals, Jews in the new United States also participated in this enthusiasm. They were convinced that in the new land Christians were different. In 1806, Myer Moses in South Carolina, who was "so proud of being a sojourner in this promised land," invoked New Jerusalem in an address to the Charleston Hebrew Orphan Society. From the time of the Declaration of Independence, "the Almighty gave to the Jews what had long been promised to them, namely, a second Jerusalem!"²

But these Jews had remained part of that persecuted collective with the millennial-old designation of Am HaTorah, which can be translated to mean People of the Talmud; its untranslated Hebrew Bible did not contain the Christian concepts or expressions of "promise." ${ }^{3}$ How should we think of them? Not as "American Jews," "Jewish Americans," "Jewish People," nor for that matter as the "People of the Book," a designation usually meaning the earliest Jews of the three monotheistic religious people of the Bible. How should we think about them as a changing people of the Talmud?

Conventional accounts by United States historians usually report that Jews and Christians, in their theoretical hostility and in their neighborly practices, in their attitude towards each other, were different here than in Europe. But in the nineteenth and early twentieth century 
there appear to have persisted European-like traditions about Jews, their heritable characteristics, and their Talmud-derived patrimony of collectivity. ${ }^{4}$ These are not easy to detect. When writing about Jews in America the vocabulary of choice was and remains to be "Biblical," "Post-Biblical," "Patristic," "The People of the Book," or for that matter, "rabbinical," or "orthodox," "liberal," or "reform." Among scholars "Talmud" in this context is conspicuous by its silence.

My project has two parts. The first part demonstrates that Jews were in fact a changing people of the Talmud. Even though I make some references to it, discussion of that large subject awaits further investigation. The second part of the project is to identify and evaluate reputations of Jews as a People of the Talmud. An aspect of that work is the primary concern of this article.

In beginning the exploration of a Talmud-focused reputation in the American Promised Land, I have turned to a select group of articulate nineteenth century Anglo-American Christian rationalists: Thomas Jefferson and John Adams, writing in the early years of the century, Ralph Waldo Emerson at mid-century, and Goldwin Smith and Andrew Dixon White, two scholars, educators, and publicists at work in the closing decades of the century. In their perception of nineteenth century Jews, these patricians reflected a theoretical engagement that harbored European-like associations between Jews and Talmudic worlds of times past and present. To be sure, their New Testament framed approach also incorporated deeply rooted attitudes towards the figure of Jesus and Old Testament Jews. But readily available evidence suggests that in the nineteenth century American constructions of what has been called the "mythical" Jew, the Talmudic canon may well deserve joint billing with the Bible. ${ }^{6}$

It is well-known, especially to readers of this journal, that nineteenth century America was different than Europe, even different than the United Kingdom and Holland, where a Calvinist infused Protestantism had also helped to fashion different associations with Jews and their Talmudic connections. ${ }^{7}$ But some brief references to Europe's past are instructive here. Even as political racism was becoming a force for mobilizing public opinion, articulate publicists, who remained excitable by the Talmud and its rabbinical disseminators, sustained associations between all Jews and the Talmud. Logically, in the nineteenth century racial attitudes may have been incompatible with rigorous religious doctrines, but in practice it was different. In these decades material and political changes were creating new and influential opportunities 
for Jews in Western and West Central Europe. Then, coalitions of Christian groups and post-Christian liberal and radical movements were engaged with the political cultures and popular biological determinants of their own place and time: they organized around specific myths and objectives.

A dramatic case in point was the infamous Damascus Affair of 1840 involving a ritual murder accusation that attracted worldwide attention. Old polemics against the Talmudic world continued to hold a special place in hostile imaginations. The accusation that Jewish "holy books and specifically the Talmud," reports Jonathan Fraenkel, "sanctioned ritual murder, was perceived by the Jewish spokesmen from the first as the most dangerous aspect of the Damascus case." ${ }^{8}$ These were entangled with commonly held attitudes about presumed inherited traits among Jews. One presumptions was "the universally accepted fact that Jews had a peculiar smell," that even baptism could not remove. ${ }^{9}$ Another perspective was comparable to notions about the place of Bildung in the genuine German character or the role of the frontier in the shaping of the American character: the Talmud experience shaped Jewish character. ${ }^{10}$

Invariably, biology intruded in public affairs. In Berlin, the Jewish Community Council discovered that fact in 1881, when it fought a newspaper that had indicted the Talmud. It "cited the German law which forbade slander of all religious communities." The state prosecutor, however, found a way out. He "refused to indict," reports master historian George Mosse: "First, the Talmud was not a religious code of law ... but merely of historical interest. Second ... in attacking the Talmud the paper had not attacked the Jews as a religious community ... but only as a race and a Volk." Another telling example comes from Uri Tal's work. It illustrates what happened in a germ-conscious Germany afraid of contagion and of the incoming Ostjude. The fear had led to new Prussian rules for border control points and westward rail traffic terminating in Hamburg. In 1893, within the year of the devastating cholera epidemic in the old Hansa city, a large group of nonOrthodox rabbis in Germany publicly declared that "the Talmud and Oral Law were binding only to the extent that it could stand up to modern rational criticism and ... insisted that the oral law had no normative authority over written law." Nevertheless, the Berliner Presse of February 18, 1893, a widely read liberal newspaper, insisted that "even modern Judaism had not yet liberated itself from the authority of the oral law, and that as long as the Jews continued to teach these traditions, it would be impossible for them to integrate completely into German Society: 'As long as the Talmud will continue to exist and [to be] studied, as it is in Jewish schools, for example ... the tendentious exploitation of its contents will not cease." "11 
Finally, it is also important to point out in what spirit John Maynard Keynes made those kinds of connections in 1930. The illustration comes from a review essay by his current biographer, Robert Sidelsky. He first recalls a pre-World War I passage from Werner Sombart, the historical economist who helped to popularize among yet another generation of publicists and scholars the quite old shibboleth: the "Talmud encouraged Jews to accumulate money through usury-making money from the loan of money." In a line of secular thought about religion and economic enterprise, involving the likes of Hess, Marx, and Weber, Sombart had designated that concept as the "root idea of capitalism." In Keynes's time the stereotype was so widespread that he wrote: "Perhaps it is not an accident that the race which did the most to bring the promise of immortality into the heart and essence of our religion has also done most for the principle of compound interest and particularly loves this most purposive of human institutions." Later, reports Sidelsky, Keynes "apologized for having been thinking along "purely conventional lines.'

Race-conscious Christians in the United States had a fear of strangers in general and concern about Jews in particular. These fears combined with commonly held convictions about biologically determined human characteristics. Furthermore, Americans had apprehensions towards collectives considered threatening. Though the separation of church and state, in state after state, was becoming a practical fact for Jews and other enfranchised citizens in the antebellum republic, and even though, outside of the South, the trot of individualism and free market economics was turning into an unrestrained gallop, the federal union was still too fragile a creature for the republic's emerging national culture to be unafraid of congealed collectives, such as Indian tribes, the constant threat of mobilized rebellious African slaves, or worse, entire sections in open revolt against the Union.

To be sure, from colonial beginnings, many, but not all, New England Puritans believed there was a connection between the conversion of all Jews and the triumph of a Christianized Israel. In 1669, in the tradition of English Protestants employing Jewish exegesists in their reading of Biblical texts, Boston's young Puritan, Increase Mather, wrote his well-known apocalyptically oriented conversion treatises about the Mysterie of Israel. There he expressed sensitivity to "Judaizing" influences even as he spoke of "Talmudic Jews," and their "Jewish Rabbies," [sic] some of whom he cited for achieving textual clarity in his own work. ${ }^{13}$ The here and now preoccupations were not, however, as in Europe, with the People of the Talmud.

One was with threatening tribal native Americans. Especially in times of stress and war Anglo-American discourse constructed Indians into lethal enemies; it was marked by "children of the devil," "degrada- 
tion," "extinction," and in time, "extermination." It is helpful to recall that when war with Indian tribes had become a fact of New England life, Increase Mather's illustrious son, Cotton Mather, wrote these lines about his peoples' Indian voices. "The voices of Indians are these: they are very lying wretches, and they are very lazy wretches and they are out of measure indulgent into their children; there is no family government among them." Framing his perceptions in constructs his colonial contemporaries had fashioned, many amidst apocalyptic expectations, he knew that his own people had been punished. "We have shamefully Indianized in all those abominable things. Now, the judgments of God have employed Indian's hatchets to wound us, no doubt, by these our Indian vices." ${ }^{14}$

The bio-cultural obsession of the day was not, as in Europe, with being "Judaized"; it was with real and imagined overlapping threats, to the federal system and to the emerging American civic culture. Indians, and Mormons, who appeared for the first time in antebellum years, challenged legally constituted authority within the states and territories of the republic. Each was distrusted, for each with force might well create and maintain "a state within a state," something beyond "dependent nations" or autonomous nationalities. So the federal government used its own soldiers to enforce reservation policies on Indians and legal prescriptions on Mormons. When an entire region tried to establish a new state, the worst did happen: civil war, the cataclysmic event of the nineteen hundreds.

By the end of the century much had changed in the years following the military elimination of the Indian menace, the coercion of the Mormons, the suppression of the Southern rebellion, and the emancipation of millions of African American slaves. But at the time when mass migration poured out of the Talmudic Kingdom and headed for the United States, the American Reservation and the Russian Pale continued to have common features.

More revealing still, about the persistence of deadly bio-cultural driven obsessions in the Promised Land, were explosions occurring when emancipated African Americans strove as free individuals to migrate within America, and move through markets, occupations, and into its citizenship. With each passing day the developing segregation system looked like the one then emerging in South Africa. The worst explosion was a lynching campaign in the Lower South which lasted from the 1880s until World War I. It gave rise to a new organized spectator sport, sometimes mobilizing over a thousand unmasked light skinned citizens for one public murder of a darker skinned American citizen. Self-appointed guardians of an idealized white Anglo-American society in the Deep South used the terrifying crusade to institutionalize new arrangements. They did it, they said, in order to defend a modern 
civilization against threatening black primitives, like those other resident primitives they and their Northern compatriots had all but penned up in patrolled reservations. ${ }^{15}$

As for Jews in that different American nineteenth century, most of them conducted their lives within a fractured and splintered Talmudic tradition and Halakhic standard. They were changing, even rebelling, drawn and pulled by the force of economic and political opportunity, enlightened rationalism, and republican assimilation; some, and increasingly many more, reflected the cutting edge of that change in the direction of what would later be designated secular Jewry. But as in other migrating populations of those years, cutting edge attitudes towards collective identities and its nomenclatures usually did not embrace the majority of Jewish newcomers and their children: They had varying standards of religious observance and there were enormous variations in their knowledge of classical Jewish sources. With these, and bio-cultural convictions of their own, Jews remained in their erratic orbits around their once hallowed canon. ${ }^{16}$ That is to say, their religious culture was like a "river full of debris," to use David D. Hall's simile about New England Puritans who had migrated from England: all caught up in a "muddied, multilayered process by which culture was transmitted, one that functioned to preserve and pass along many bits and pieces of past systems of belief." corporate groups had also moved from their place in time and space, from their Sitz-im-Leben in Talmudic Judaism. Across generations, and in their masses, they began as different kinds of Talmudic Jews and went through different periods to become diverse post-Talmudic Jews. This led them to quite different futures, to all sorts of religious and ethnic Jews, of the kind so common in our day, in Israel and in the rest of the world. ${ }^{18}$ But, during the nineteenth and early twentieth century, their journeys and moves through the ranks of society did not eclipse their commitments to the Talmud and the Halakha as much as it fractured and splintered it.

Thomas Jefferson and John Adams fully appreciated these Jewish commitments. At a time when both aging giants were living in a republic that had made a sharp evangelical Protestant right turn away from the anti-clericalism of their revolutionary years, ${ }^{19}$ Jefferson quoted approvingly to Adams passages from William Enfield's summary of Johann Jakob Brucker's Historia Critica Philosophiae. One of the longer quotations stressed, not the life of Biblical Jewry but Bruckner's and Enfield's misrepresentation of the state of moral philosophy to be found in the 
Talmud. Enfield had best speak for himself since his formulation succinctly expressed the usual thinking on the subject among English Deists and French enlightened rationalists. ${ }^{20} \mathrm{He}$ cast his conclusion in terms of "the Jews in the Middle age," that is from a time between the classical world and the modern one. Jewish books of "Morals chiefly consisted in a minute enumeration of duties. From the law of Moses were deduced 613 precepts, which were divided into two classes, affirmative and negative, 248 in the former, and 365 in the latter. It may serve to give the reader some idea of the low state of moral philosophy among the Jews of the Middle age, to add, that of the 248 affirmative precepts, only 3 were considered obligatory upon women; and that in order to obtain salvation, it was judged sufficient to fulfill any one single law in the hour of death; the observance of the rest being deemed necessary, only to increase the felicity of the future life. What a wretched depravity of sentiment and manner must have prevailed before such corrupt maxims could have obtained credit! It is impossible," he concluded, "to collect from these writings a consistent series of moral Doctrine." No wonder the enlightened Jefferson in 1803 had informed Benjamin Rush that all Jews "need reformation ... in an eminent degree."

In their exchanges the unreconstructed anticlerical republicans from Virginia and Massachusetts revealed the nature of their interest in the classical sources governing the People of the Talmud. Steeped in Greek and Roman sources, and eager to remain conversant with the non-Jewish English, French, and German literature of the European and American Enlightenment of their own day, they differed about the value of the ancient Hebrews' contribution to progressive religious thought. Some years earlier, Adams had written "I will insist that the Hebrews have done more to civilize men than any other nation.... The Jews ... preserve[d] and propagate[d] to all mankind the doctrine of a supreme, intelligent, wise, almighty sovereign of the universe, which I believe to be the great essential principle of all morality and consequently of all civilization." ${ }^{22}$

Both shared the instrumental approach of most European critics to classical Jewish texts, about which, by their own admission, Jefferson and Adams also knew next to nothing. But as those critics did, they too comprehended that the classic Talmudic corpus of Judaica provided the constitutional web of Jewish conduct for the few thousand Jews in their midst, the tens of thousands in the English, French, and German parts of Western Europe, and the hundreds of thousands east of the Oder and in the Near East. In that respect there was little to distinguish between them and Henry St. John Bolingbroke, Voltaire, or for that matter Joseph Priestley, who had died in $1803 .{ }^{23}$

It was the publication of one of Jefferson's letters to Priestley that 
had stimulated Adams to press Jefferson for the exchange of views about Jews in the first place. Although they had misgivings about some of his Christian beliefs and intellectual presumptions-especially Adams, whose connections to Priestley had been quite different than those of Jefferson's close ties-both presidents held him in high regard. Priestley, the famous English political thinker and scientist, was part of a group that Adams had met and valued while posted to London from 1785 to 1787. "Unitarianism and Biblical Criticism were the great Characteristics of them all. All were learned, scientific, and moral.... All professed Friendship for America, and these were almost all, who pretended to any such Thing." During the French Revolution Priestley was driven to the United States by an angry Birmingham mob and remained in Pennsylvania until his death. ${ }^{2}$

But there was another side to Priestley that the two friends commented upon but did not explore. In England, in 1786 and 1787, in a storm of controversy, and again in 1794 in the United States, Priestley had published his Letters to the Jews. The well-advertised pamphlets were part of his campaign to convert Jews to his kind of persuasion. As had the earlier critics, Priestley, a Unitarian minister, also pressed a Scripture-based Christian intellectual polemic without examining Jewish life on its own terms. ${ }^{25}$ He could easily have done so. In London of those years, when "an impressive fiscal military state," "an articulate and powerful middle class," and a vibrant Dutch-like consumer economy was changing the nature of English nationalism, it was easy enough to find knowledgeable Sephardic and Ashkenazi Jews in their institutional setting and with their familial, religious, and commercial connections to Holland and Germany. He had available all sorts of contemporary descriptions of London Jewish life written by resident and touring Jews or Christians. Some publications were indictments and misleading, such as those which continued to designate the officiating rabbi in a synagogue as a high priest; it was a designation with a remarkable vitality in the nineteenth century. Other accounts were accurate and sympathetic. Of course, Priestley, as well as the two former presidents, could have turned to the German-language works of Moses Mendelssohn. These, issued between 1756 and 1787, included his published rational defense of Judaism against enlightened attacks and conversion efforts. When diplomats Adams and Jefferson were in London and in Paris, Mendelssohn had become well-known among Europe's philosophes. ${ }^{26}$

Finally, Priestley could have taken much more seriously than he did the published counter-attacks by David Levi. To be sure, Levi, an Anglo-Jewish London-born "failed shoemaker and sometime hat dresser," was not comparable to a Mendelssohn. But Levi had become accomplished in his self-appointed task to study Jewish tradition and defend it against "gentile calumnies." In 1783, he had published A Suc- 
cinct Account, of the Rites, and Ceremonies, of the Jews, a large work that included a summary of the ancient Mishna, which had attracted English Protestants since the seventeenth century. And a few years later, he brought out "a quite extraordinary and very large three volume work on the Hebrew language, consisting of a Hebrew grammar, a Hebrew English dictionary comprising all of the vocabulary of the Old Testament, and an English-Hebrew phrase book." ${ }^{27}$

In examining Priestley's references to Scripture and conversion polemics addressed to Jews, Levi used his Jewish knowledge with the firm conviction that it was as valid, if not more so, than Priestley's New Testament driven Protestant interpretations of Scripture and nonJewish classical sources. Indeed, in that same spirit Levi also turned to the Talmudic corpus of Jewish truth and knowledge when he cited parts of it in his published critique of Tom Paine's reading of the Old Testament. So, no matter how strongly he insisted on basing his arguments on Scripture, Priestley knew Levi was writing from within the People of the Talmud whose sources, to Priestley, were invariably suspect. He dismissed Levi's arguments and sources out of hand. ${ }^{28}$

Some of Priestley's other contemporaries also found fault with his Letters to the Jews. One was an imaginary Solomon de A. R. who wrote him a public letter. "There is a degree of candor and benevolence (real or affected you best know) running through your Letters, which could not avoid being extremely pleasing were it not for that air of superciliousness and superiority, with which the whole is contaminated. The persons to whom you address yourself, appear in your Letters to be little better than contemptible children, or idiots, incapable of attending to solid manly arguments, and therefore to be amused with gewgaws and trifles."29

Adams too was critical, but for reasons having to do with Priestley's acceptance of all sorts of Christian beliefs: Jesus had a divine mission, had created miracles, had been resurrected, and would "come again to raise the dead and judge the world." For these beliefs Adams could find no rational explanation nor textual evidence in his reading of Scripture. "I shall never be a Disciple of Priestley. He is as absurd inconsistent, credulous and incomprehensible as Athanasius. Read his Letter to the Jews in this Volume. Could a rational Creature write it? Aye! such rational creatures as ... Condocet[sic]...John Taylor in Politicks ... and French Prophets in Theology."

Jefferson was more restrained, and actually examined Levi's response to Priestley. "It is a curious and tough work. His style is inelegant and incorrect, harsh and petulent to his adversary, and his reasoning flimsy enough.” But, he acknowledged, Levi had introduced him to some Jewish doctrines which were new to Jefferson and he now summarized for Adams Levi's passages about Jewish monotheism and 
about Jesus. "He alledges[sic] that the Jews alone preserve the doctrine of the unity of god. ... He agrees than an anointed prince was prophecied and promised: but denies that the character and history of Jesus has any analogy with that of the person promised." Jefferson faulted Levi's methodology. "For example, he takes passages from Scripture from their context (which would give them a very different meaning) strings them together, and makes them point towards what object he pleases; he interprets them figuratively, typically, analytically, hyperbolically; he calls in the aid of emendation, transposition, ellipsis, metonymy, and every other figure of rhetoric ... and finally avails himself of all his advantage over his adversaries by his superior knowledge of Hebrew, speaking in the very language of divine communication, while they can only fumble on with conflicting and disputed translations." However, Jefferson, taking the measure of both, gave Levi his due even as he protected Priestley. "Such is this war of giants. And how can such pigmies as you and I decide between them. For myself I confess that my head is not formed tantas componere lites," quoting for Adams a line from Virgil ("It is not for me to settle for you such great arguments") as he closed his letter in the spirit that Adams had last written to him about philosophy, politics, and metaphysics: "And as you began your Mar. 2. with a declaration that you were about to write me the most frivolous letter I had ever read, so I will close mine by saying I have written you a full match for it.".31

Jefferson and Adams had a sense of the Judaic corpus they would have to master in order to properly compare and evaluate Jews and Judaism in thought and action. Here is Jefferson: ${ }^{32}$ "To compare the morals of the old, with those of the new testament, would require an attentive study of the former, a search thro' all its books for its precepts, and through all its history for its practices, and the principles they prove. As commentaries too on these, the philosophy of the Hebrews must be enquired into, their Mishna, their Gemara, Cabala, Jezirah, Sohar, Cosri, and their Talmud must be examined and understood, in order to do them full justice."

And here his friend Adams: ${ }^{33}$ "If I had Eyes and Nerves I would go through both Testaments and mark all that I understand. To examine the Mishna Gemara Cabbala Jezirah, Sohar Cosri and Talmud of the Hebrew would require the life of Methuselah, and after all, his 969 Years would be wasted to very little purpose. The Daemon of Hierarchial despotism has been at Work, both with the Mishna and Gemara. In 1238 a French Jew, made a discovery to the Pope . . of the heresies of the Talmud. The Pope sent 35 Articles of Error, to the Archbishops of France, requiring them to seize the books of the Jews, and burn all that contained any Errors. He wrote in the same terms to the Kings of France, England Arragon, Castile Leon, Navarre and Portugal. In 
consequence of this Order 20 Cartloads of Hebrew Books were burnt in France: and how many times 20 Cartloads were destroyed in the other Kingdoms? The Talmud of Babylon and that of Jerusalem were composed 120 to 500 Years after the destruction of Jerusalem. If [John] Lightfoot derived Light from what escaped from ... [the Pope's] fury in explaining many passages in the New Testament by comparing the Expressions of the Mishna, with those of the Apostles and Evangelists, how many proofs of the Corruptions of Christianity might we find in the Passages burnt?"

But it is important to reiterate that the context of these and related passages about the People of the Talmud were enthusiastic private speculations by aging giants of the American Enlightenment-Adams designated his as "School Boy criticisms and crude Philosophy, problematic History and heretical Divinity"-about the pagan religious inspirations and values they associated with New Testament passages attributed to Jesus. In their case that enthusiasm was driven by an eagerness to demonstrate what Adams had identified as the "Corruptions of Christianity." The speculation is that the best of Christianity is not uniquely dependent on Jews; for their comparative reading had also revealed that rational religion was inherent in the natural religion of pagan writers. ${ }^{34}$

Modern historians writing about Jews in antebellum America have not followed a lead in Isaac Mayer Wise's recollection about English missionary inspired anti-Semitism: "the Talmud and, incidentally, the Jews and Judaism were attacked . . . erelong . . . every pastor and every insignificant little preacher, every common jester, and every political rogue rained blows upon the Talmud and the Jews . . . and all this called forth not one word of protest from any source." 35

There were some among middle and late nineteenth century "enlightened" Christians who expressed their respective versions of aging views about the Talmud and its people. Witness the elusive Ralph Waldo Emerson. To be sure, the evidence that he also perceived Jews as a People of the Talmud is more circumstantial, if only because in the few passages he did write about Jews he did not explicitly refer to the Judaica corpus in the manner of Jefferson and Adams. But he too did not write in isolation from his surroundings. His Jewish contemporaries in New England, or in Italy and the United Kingdom, where he visited, may have "figured peripherally" in his daily affairs. But that was by his choice and surely did not preclude this intellectual giant from knowing that the Jews of his written passages were in fact the changing 
People of the Talmud. In his lifetime expressions of and protests against Talmud phobia popped up in some books and news stories published in the United States. By the end of August, 1840, American cities on the eastern seaboard witnessed Jewish protest meetings about the Damascus Affair; resolutions were sent to the White House. And, after the Affair, an English-language Jewish press emerged in England and in the United States which in Boston or London, with some effort on Emerson's part, was available to him. It is also not unimportant to note that until the $1850 \mathrm{~s}$ most, if not all, of the thirty-seven Jewish congregations in the United States were religiously orthodox; three of those were in Boston, including one, when Boston's Jewry was tiny, that was comprised of Polish Jews from Poznan. ${ }^{36}$

Besides, there were instructions from his literary world. In 1822 William Croswell, who seems to have shared Christian missionary sentiments towards Jews, wrote a poem entitled "The Synagogue," which, in 1842, was the only poem in Rufus Griswold's Poems and Poetry in America that dealt with contemporary Jewry. Its lines, connected to the Pharasees, nevertheless included: "I saw them in their synagogue/As in their ancient day..." and called attention to "holy Sabbath eve," "Phylacteries," "fringes," and "mighty scroll." Henry Wadsworth Longfellow, whose approach to the Talmud and the Hebrew language was quite different from that of Croswell and Emerson, used "Talmud," "Targum," and "Kabala" in his "Tales of a Wayside Inn."

And then there was Henry Holt Milman. Starting in 1832, Emerson had available the work of this classicist who published the first of a number of editions of his three volume history of the Jews. The first edition is listed in the bibliography of Emerson's library, as recorded by the Concord Antiquarian Society. Some of Milman's passages are noteworthy for identifying the kind of English-language knowledge available to mid-century American men of letters. In comparison to Jefferson and John Adams, Milman's passages reflected a greater awareness of the Judaica corpus and, on its own terms. I quote at length from the 1866 edition:

The influence of the Talmud on European superstitions, opinion, and even literature remains to be traced; to the Jew the Talmud became the magic circle within which the national mind patiently laboured for ages in performing the bidding of the ancient and mighty exchangers, who drew the sacred line beyond which it might not venture to pass.... [As result of persecution it] became more dear to the Jew, who was little inclined to unfold its lore to the blind prejudiced Christians unable to comprehend; and unworthy of being enlightened by its wisdom. . . [ [It would] require a perfect mastery of Rabbinical Hebrew in its gradual development and expansion, as well as calm and subtle and penetrating, I would almost say, considering the subjects often in discussion, a reverential judgment-the gift of a few men, of still fewer who are likely to devote their minds to what after all might prove but a barren 
study. So alone should we know what the Jews have been, what they may be, and fully understand their writing and their later history. A religious mind would be above all indispensable, but the combination of religious zeal with respect for the religion of others is the last and tardiest growth in the inexhaustible soil of Christian virtue.

By citing reputable scholars, who had taken pains to distinguish between the Halakha on the one hand and the Midrash and Agada on the other, Milman made certain that readers such as Emerson would not be misled by the kinds of misrepresentations presented by the likes of Enfield. ${ }^{38}$

Students of Emerson have placed him in all sorts of contexts. Baritz represents one main line of thought: "Steadily elevating law, system, and some fundamental word-the Bible or the United States Constitution-above any person, American thinkers had characteristically sought ways by which to return to a Hebraic God who was pure idea, pure 'I Am,' and who had told the prophet Samuel to tell the Jews to beware of Kings. Americans had characteristically sought to purge the flesh and personification from their world views, and in so doing they rejected the continuity of the generations of men." Within that stream Emerson came to declare humans divine and, in a flight of transcendence, predicted if each "would be true to his own divinity each would attain the kingdom of the just." "

Robert J. Lowenberg has another context and within it he detected serious "Jew hatred." Emerson's goal as a poet is "what [Harold] Bloom claims it is-divinity.... So what god... [does], Emerson competes ... with. . . Emerson sought to enthrone the god who is 'One Man' in place of the God who is One, in place of the God of the Jews." But according to Lowenberg, Emerson was after much more: "Emerson hoped to bring about the suppression of God, in addition to that of Torah and Israel. ... [His] revision of Judaism is radical and thorough. It begins with revision of God. Naturally the Church and all that comes after it, and not just Torah and Israel, are superseded." The poet “... becomes the new suffering servant." ${ }^{\circ 0}$

That reading may stand alone, in part because of Emerson's Lamarckian-like passages about the transforming power of the AngloAmerican republic. He wrote: "in this continent-asylum of all nations-the energy of Irish, Germans, Swedes, Poles, and Cossacks, and all the European tribes ... will construct a new race, a new religion, a new state, a new literature." Emerson's positions were also influenced by racial attitudes among publishing biologists and anthropologists. So, for example, that asylum passage is implicitly qualified by later passages on race. It works "immortally to keep its own," but it is also resisted by such other forces as "Civilization," a "reagent" eating away "the old traits," but not for all. Emerson wrote: "Race is a controlling influence 
in the Jew, who for two millenniums, under every climate, has preserved the same character and employments. Race in the negro is of appalling importance... . But the Briton of today is a very different person from long ago. Each religious sect has its own physiognomy. The Methodist have acquired a face; the Quakers a face; the nuns, a face. Trades and professions carve their own lines on face and form."

Lowenberg's interpretation, however, does also suggest, when it comes to Jews and their Judaism, Emerson thought of Jews not only as the People of the Book but also as the primitive People of the Talmud. Lowenberg claims that "Emerson routinely identified Jews as usurers and low-minded people." He certainly had Jews on his mind when, from time to time, he made entries in his journal. In 1832, he noted: "And God had his scaffoldings. The Jewish Law answered its temporary purpose \& was then set aside. Christianity is completing its purpose as an aid to educate man. And Evil is a scaffolding on which universal good is reared. God shall be all in all." A year before the Damascus Affair and before beards had become stylish for New Englanders, after a visit to a Boston gallery where he saw one or more of Washington Allston's "A Sketch of a Polish Jew," Emerson, without losing his critical distance, noted that "the Polish Jews are an offense to me; they degrade and animalize. As soon as a beard becomes any thing but an accident, we have not a man but a Turk or a Jew, a satyr, dandy, a goat. So we paint angels \& Jesus \& Apollo (with) [sic] beardless; and the Greek \& the Mohawk leave them to Mufties and Monks." To be sure, Emerson was a sharp critic of Allston's work-it had included many beards in portraits representing Biblical scenes-because he considered the apocalyptically oriented Allston too much a prisoner of traditional Christian European culture. But the reaction to Polish Jews-"they degrade and animalize"-was Emerson, not on Allston nor on the beard worn by the face in the portraits; it was Emerson on the People of the Talmud. Allston's title for the portraits had triggered the response. ${ }^{42}$

Like John Adams, Emerson had recognized the significance of Hebraic monotheism in the Second Commandment but was pressed to move beyond Adams and that commandment: "In taking this PM farewell looks at the sybils \& prophets of Michel Angelo, I fancied that they all looked not free but necessitated; ridden by a superior Will, by an Idea which they could not shake off. It sits in their life. The heads of Raphael look freer certainly, but this Obedience of Michel's figures contrasts strangely with the living forms of this age. These old giants are still under the grasp of that terrific Jewish idea before which ages were driven like sifted snow which all the literatures of the world,Latin, Spanish, Italian, French, English, tingle with, but we sleek dapper men have quite got free of the old reverence, have heard new facts 
on metaphysics, \& are not quite ready to join any new church. We are travelers, \& not responsible."

On May 17, 1840, by which time news about the Damascus Affair had started to appear on the pages of some of America's leading newspapers-it had been receiving important coverage in England, France, and Germany for two months-he noted, without explanation: "It seems as if the Jews harp has sounded long enough." (He never did explicitly comment on Damascus.) A decade later, perhaps in a string of thought that still connected him to Priestley's kind of Unitarian conversion efforts, he envisioned the end of the People of the Talmud, although he did not put it that way. "Tis said that the age ends with the poet or successful man, who knots up into himself the genius or idea of his nation; and, that when the Jews have at last flowered perfectly into Jesus, there is the end of the nation."

Emerson certainly continued to think of Jews as "base"; for years later in the midst of Reconstruction, comes this passage: "You complain that the negroes are a base class. Who makes \& keeps (them so.) the jew or the negro base, who but you, who exclude them from the rights which others enjoy?" And in 1864, embedded in a passage reacting to the turmoil of Civil War, he revealed some familiarity with rabbinical commentaries on the Hebrew's Bible: “American Nationality is now within the Republican Party, hence its security. In like manner, (the cause) in view of the nationalities of the world, the battle of humanity is now in the American Union, \& hence the weakness of English \& European opposition. Napoleon's words that in 25 years, the United States would dictate the policies of the world, was a little early; but the sense was just, with a Jewish interpre(ta)tion of the 'forty days' \& seventy weeks. It is true, that if we escape bravely from the present war America will be the controlling power." 43

In order to make the obscure less opaque among nineteenth century influential Anglo-Americans writing in the Christian rationalist tradition, I turn to Goldwin Smith and Andrew Dixon White. The first expressed himself most explicitly about the People of the Talmud; the second was also explicit but, in addition, was well connected to leaders of the small but growing number of Jews who identified with Reform Jewry. Together, though for different reasons, they all accepted this proposition: an inherent part of the changing People of the Talmud was pious, or religiously observant enough to consider the Talmud and its rabbinical interpreters as exclusive sources of truth and knowledge. 
Therefore, this Jewry, a primitive medieval orthodoxy, was in conflict with modern life.

This perspective of the critics occurred against a background being littered by neo-Lamarckians. They could not but stamp new sciencegerm theory oriented biology-on all sorts of bio-cultural beliefs rooted in traditional notions about familial transmission of acquired characteristics. Some fifty years before the publication of Origin of the Species, J. B. Antoine de Lamarck, a French evolutionist, had taken a concept about the inheritance of acquired characteristics, "so universally accepted from the ancients to the nineteenth century ..." that there was "no need for ... [him] to enlarge upon it." He simply made it part of a larger complex explanatory model of evolution. His "paradigm was highly persuasive to the lay person, who held most of the beliefs of which it was composed. This is the reason," writes Ernst Mayr, the distinguished historian of biological thought, "why some of the Lamarckian ideas continued to be accepted so widely for almost a hundred years ..." after the publication of Darwin's Origin. Indeed, the concept of newly acquired characters "was so universally accepted... that when Lamarckians had a revival toward the end of the nineteenth century, most of those who had never read Lamarck in the original assumed that Lamarckism simply meant a belief in the inheritance of acquired characters."

There were all sorts of implications. By this light a species' capacity to hold its critical environment constant sustained its capacity to inherit its acquired characteristics. Such assumptions did not have to lead to pessimistic expectations. In line with the optimism of enlightenment thought, Lamarck had believed that "no race was eternally locked into its present characteristics." Others too took an optimistic, even a radically optimistic, reading of the days to come-the revolutions of capitalism, liberalism, and democracy will transform the environment which in turn will fashion a person with new desirable heritable characteristics. But, even though Lamarck had thought that "idleness, carelessness, and lack of success were not racial qualities ..." he did recognize them as characteristics acquired as "the result of the habit of submitting to authority from early youth." So, amidst growing fears in the struggle for survival-those who deemed themselves superior peoples felt themselves seriously challenged by those they considered as inferior, dangerous, and degenerate-Lamarckians focused on persistent training environments for the young. ${ }^{44}$

Indeed, as in the case of Sigmund Freud, who rejected much of the racial attitudes so popular among his fellow physicians, the writings of Jews among them revealed the influence of neo-Lamarckism especially well. Yosef Hayim Yerushalmi's insightful observations about Freud illuminates the landscape. He has suggested that "Freud's Jewish- 
ness may ... also have played a role in his Lamarckian predilections" in the sense that "its subjective dimension, the feeling harbored and expressed by committed and alienated modern Jews alike, of the enormous weight, the gravitational pull, of the Jewish past, whether it be felt as an anchor or a burden." Yerushalmi argued: "Deconstructed into Jewish terms what is Lamarckism if not the powerful feeling that, for better or worse, one cannot really cease being Jewish, and this not merely because of current anti-Semitism or discrimination, and certainly not because of the Chain of Tradition, but because one's fate in being Jewish was determined long ago by the Fathers, and that often what one feels most deeply and obscurely is a trilling wire in the blood." Freud, in writing about the Land of Israel, put the point this way: "and we hail from there ... our forebears lived there for perhaps a whole millennium ... and it is impossible to say what heritage from this land we have taken into our blood and nerves." ${ }^{45}$

Euro-American physicians among Freud's contemporaries no longer assumed the Jewish male menstruated, but they still attributed to Jewish men and women all sorts of other peculiar characteristics and habits, in part because they ignored contrary evidence being published by Jewish colleagues. ${ }^{46}$ Experts continued to construct Jews as being impervious to the different climates and lifestyles in which the world's Jews lived. Racial immunity or "a hereditary aversion to liquor" protected them from alcoholism; they also had not succumbed to plague and pestilence "to the same extent" as had non-Jews. In similar fashion, but usually determined by the current events of their practice, doctors often made all sorts of assumptions about the Jewish stranger or neighbor next door, widely believing all sorts of things: they were not as susceptible as Gentiles to typhus, tuberculosis, cholera, measles, scarlet fever, diphtheria, or croup; in proportions significantly higher than non-Jews, Jews did suffer from diabetes, lung and bronchial problems, hemorrhoids, cancer (" . . but neither penile nor uterine, due to male circumcision ..."), conjunctivitis, trachoma, and color blindness. In Germany's biomedical culture, social construction of disease and illness led to the general conclusion that Jews, though as individuals belonging to the white race, collectively constituted a separate racepure, bifurcated, mixed, or racially separate by virtue of its unique religious community. ${ }^{47}$

Goldwin Smith was brought to Cornell by President White to join the faculty as a nonresident Professor of English and Constitutional History. He stayed for three years before moving on to Toronto. Smith 
had been Oxford University's Regius Professor of History for eight years and had established a significant reputation as a liberal publicist opposed to religious orthodoxies, especially to those of the Jews. He wrote about them based on sources associated with the genre of European anti-Semitic writings during the last third of the nineteenth century. In Canada, he continued his teachings and writing, and also his occasional correspondence with White. ${ }^{48}$

In the late 1870s and early 1880s, Goldwin Smith, who had long believed Jews prevented England from conducting an independent foreign policy towards countries with large Jewish populations, liked to distinguish between "liberal" Jews and "genuine" Jews. The relatively few liberal Jews in enlightened countries "have virtually ceased to be Jews. ... So rapid is the progress of [their Judaic] disintegration ... as to render it probable that in a few generations Judaism will cease to exist [there]." "One can hardly imagine," he wrote in 1878 in Nineteenth Century, "that anything palpably primeval and tribal would long resist the sun of modern civilization, when a wise and tolerant policy once allowed that sun freely to shine upon it. ${ }^{49}$ Genuine Jews, in their migrating masses out of Eastern Europe, frightened him. That bright sun could not penetrate and therefore would not disintegrate what he, in American slang, called that Jewish "hard shell type." Genuine Jews were not like Unitarians or Methodists, people having "merely a religious belief" that in no way affected their "secular relations" with other citizens: "Judaism is a distinction of race, the religion being identified with the race as is the case in the whole group of primeval and tribal relations." For Smith the genuine Jew was a person "with a special deity of his own race. The rest of mankind are to him not merely people holding a different creed, but aliens in blood." By 1881, he declared: "Israel is not a sect, but a vast relic of primeval tribalism, with its tribal mark, its tribal separation, and its tribal God. The affinity of Judaism is not to nonconformity but to caste."

Goldwin Smith, perceived by contemporaries on both sides of the Atlantic as a modern, liberal, tolerant political activist and distinguished academic, represented himself as a general critic of all religious orthodoxies. In the kind of scholarly fashion he shared with Heinrich von Treitschke, the popular Prussian historian to whom he was often favorably compared, Smith was eager to expose the source of that Judaic primeval tribalism which so effectively shielded itself from the disintegrating rays of the modern sun.

He buttressed his arguments with Biblical texts, especially passages about rituals of circumcision and injunctions against intermarriage. He described Jews in their ancient historical setting as a "community of husband men" who, even as they had demonstrated their capacity for intolerance, had produced "a great religion," and "memorably contrib- 
uted to the progress of humanity." From there he extended his remarks to post-Biblical Jewry and well beyond. He knew there was a connection between Biblical days and a much later Jewish priesthood. When rabbis wielded the "civil sword" they rejected a posture of tolerance towards those whose expressions and deeds differed from the priesthood: The works of Maimonides were burned. Excommunication choked freedom of thought. And in the Poland of his time, Goldwin Smith reported "bigotry capable of anything is to be found among the zealots of the Jewish race."

In fact, Smith often relied on information he obtained from James Laister, an English correspondent whom he paid for his services as an informant about the Talmud, about which Goldwin Smith apparently knew nothing. Laister, a Methodist minister, who aired his own views in Modern Thought, usually stressed the significance of the Talmud in linking Biblical Jewry to the present. He followed Christian arguments that had been advanced since at least the thirteenth century: "the Jews, whom we are now discussing have not given us the Bible, they have given us the Talmud ..." which he insisted was the "modern application of Mosaic Laws in hostility to gentiles." ${ }^{50}$ With Smith, he saw Jews as people standing in the way of progressive civilization. Modern "genuine Jews" were not scriptural Jews at all. "Russian Jews are Talmudic." ${ }^{51}$ Laister, himself actually ignorant about the content of the Talmud, was eager to push this campaign with Goldwin Smith. In the spring of 1882 he found a Talmud expert he could trust and use for their mutual needs, a Jewish convert to Christianity. "I am going to tell him ... that what is most needed is direct evidence that the teaching of the Talmud is actually operative now. We know it is," he wrote Smith, "but we want proof. We are met at present in two ways, first it is not in the Talmud, or else it means something different ... We know nothing of the Talmud," he acknowledged, "it is a sealed book to all but a few Jews." Certainly, Laister and Smith knew nothing: the newly found Talmud expert seemed astonished at their ignorance when he realized, reported Laister, that Laister had no appreciation of the relation between the Talmud and Jewish conduct. The convert said: "It is true that to most Jews the Talmud itself is a sealed book, but its sayings, its proverbs, its maxims have eaten themselves into the daily life and conversation of the race. The Book is not read, but its spirit is everywhere." Laister must have been astonished for other reasons as well. He reported on newly acquired information about the details of ritual circumcision and about something all "genuine Jews" wear: "a scarf fit with tassels ('fringe') ... under the waistcoat (not to be confounded with the scarf worn at worship)"; it is "called the 'four corners'-Arba Can Foth." He also felt compelled to apologize to Smith for misleading him about one of the newly acquired details Laister had obtained. "I 
made a mistake when I told you that Jewesses wore wigs to conceal premature baldness. It is a fact that they fade very early, but the wig is explained in this way. When she marries (in orthodox countries) she is shorn of her hair the next morning, and ever afterwards wears a head covering peculiar to-that is to say it differs in different countries." In England and America "where the Jews are semi-gentiles as regards exteriors" a simple wig so as "not to look singular ... generally ... is worn only by foreigners of whom there are now a great number in London." 52

Goldwin Smith integrated this type of knowledge within the neoLamarckian thought that framed so many responses to the mass migration of Jews out of the Old Polish Kingdom, that is from Russia, Austria-Hungary, and from the Prussian Duchy of Poznan. They were primeval tribal people, dangerous because Smith believed in the inheritance of acquired characteristics. That belief was ambiguous enough to allow him to capriciously identify habits, instincts, occupations, or some other characteristics he found harmful as Jewish, because the hard shell protected Jewish particularity from the progressive forces of evolution and enlightenment. In 1881 one English contemporary applied the general analysis this way: "The fact that during a long period... [Jews] were absolutely driven into money-dealing as their sole business, seems to have developed a heredity faculty of accumulation." ${ }^{23}$ Laister argued from remote causes. Whatever he found abhorrent in the conduct of Jews in the Old Polish Kingdom was a "logical outcome of their religious teaching and social training." He had identified a critical sustaining mechanism for that conduct by pointing to the institutionalized practices of training the young of each generation. Goldwin Smith agreed, in his way. The Jews "have now been so long a wandering race, 'preferring to earn their living with their heads,' that the tendency is ingrained, and cannot be altered by anything that Christendom can do." The condition was part of a general phenomenon. "The same thing would probably have befallen the Greeks had they, like the Jews been permanently converted into a race without a home. For such habits, whether formed by an individual or a race, humanity is not responsible, nor can it prevent them from bearing their natural fruits." And there was this fact to consider: "Judaism is Legalism, of which the Talmud is the most signal embodiment. ... In the competition of this world's goods it is pretty clear that the legalist will be apt to have the advantage and at the same time that his conduct will often appear not right to those whose highest monitor is not the law." Thus, the professor of political science and history could reach this general conclusion: "in whatever camp the Jew is found he will be apt for some time, unless the doctrine of heredity is utterly false, to retain the habits formed during the eighteen centuries of itinerant exis- 
tence, without a country and under circumstances which rendered cunning, suppleness, and intrigue almost as necessary weapons of self defense in his case as the sword and the lance were in the case of the feudal soldier." ${ }^{54}$ Jewish migration out of the East was dangerous. It was one thing for Smith, and those who concurred, that "men of Jewish descent who have put off tribalism altogether" are to be welcomed as citizens in the fullest sense of the term, and that the welcoming society should "rejoice in any good gifts, peculiar to their stock, which they may bring to the common store." bonds between "liberal" Jews and the masses of hard-shelled "genuine" Jews streaming west. "The common people know nothing about Lessing and Nathan Der Wise; and if they did," Smith explained, "they might say with truth that the character of Nathan Der Wise is as fictitious as that of the Eastern sages of Voltaire."

Smith looked for ways to protect liberal political economies and their progressive civilizations from this specter of the Middle Ages. General principles of Manchesterian economics required his opposition to restraints on migration within the Euro-American world, but this Jewish migration coming out of the Old Polish Kingdom required special treatment demanded by a "case of absolute necessity." The "land of every nation is its own," explained Smith. "The right of self defense is not confined to those who are called upon to resist an armed invader. It might be exercised with equal propriety, though in a different way, by a nation the character and commercial life of which were threatened by a great irruption of Polish Jews. The Americans think themselves perfectly at liberty to lay restrictions on the immigration of the Chinese, though the Chinaman with his labourer's shovel is nothing like so formidable an invader as the Jew." ${ }^{, 56}$

Before turning to Andrew Dixon White, it is useful to suggest that some of Smith's positions may have served as White's unspoken notions for his own discussion of Russian Jewry and its migration. For one, Smith's misrepresentations of the Talmud are not all that different from Enfield's and, by extension, from views Jefferson helped promulgate in private. For another, Smith shared with White a republican animus toward all clerics. This reached back to the post-Christian paganism of the Enlightenment, especially to the Deists who attacked the ancient Hebrews of the Old Testament and the Jews of the eighteenth century.

Finally, it is helpful to recall that White moved comfortably in circles that included Henry Adams, whose "Jewish passages," which are 
usually associated with status and race, also need to be connected to specific attacks on Jews who lived in orbits of Talmudic prescriptions. Between his "Virgin" and his "Dynamo" the great American medievalist exhibited classic metaphors he and his contemporaries understood only too well. Two well-known examples will suffice. In the early twentieth century in the famed Education, he did not have to explain why he was starting his autobiography with Israel's Temple, the circumcision ritual, and his "uncle the high priest, under the name of Israel Cohen," any more than why he was claiming that his sense of place in post-Civil War America was threatened by Polish Jews "still reeking of the Ghetto, snarling a weird Yiddish." They were, it was well known, medieval, living in a traditional framework of conduct and beliefs derived from the Talmud. ${ }^{57}$ In 1906 he wrote his brother Brooks, "God tried drowning out the world once, but it did no kind of good, and there are said to be four-hundred-and fifty thousand Jews now doing Kosher in New York alone. God himself owned failure." ${ }^{, 58}$ Surely then, there are good reasons for suggesting that Smith's views can be understood as containing some of the preconditions for White's attitude about Talmudic Judaism. Its practitioners did not occupy a place in his race-conscious imagination that the likes of Indians and Filipinos did. But in general, these views of his were all part of the progressive vision's pessimistic side. $^{59}$

White spoke with an American Protestant anticlerical voice. He was certain that Anglo-Americans and Germans had developed the Christian civilization that was moving humanity ever closer to the kingdom of heaven on earth. Translated into practical terms, that outlook justified for White territorial conquest and the removal and containment of dark skinned pagans. As a young man, in 1853, he had supported continental expansion to the south and west because it made inevitable the spread of republican Christianity. In 1902, when American soldiers occupied the Philippines, he wrote President Theodore Roosevelt: "I consider the destruction of a whole Indian tribe or a whole island full of low class half-breed Malays and other savages as of infinitely less account than the blotting out of a single God-fearing, hardworking, American pioneer family." ${ }^{60}$ For the nonpagan population, White turned to the "correct" kind of education that antebellum white Protestant middle class reformers had urged as appropriate for laundering the political minds of unwashed men who were becoming voting citizens of the republic. As president of Cornell University he had insisted that the nation's elite have university training that made them appreciate the importance of Christian values and military training. Both were essential for staying the course and protecting the republic against unruly and misled urban mobs. White had espoused emancipation and integrated schools for the freed slaves and their fel- 
low citizens. But by the 1890 s he, as did so many northern influential whites, had come to see "some beautiful relations" within slavery which were forever lost. Rapid, dramatic transformation of millions of blacks into full and equal participants of the republic was obviously beyond reach. They and the nation would have to wait. Instead of depending on the popular oral traditions within African American life, which in fact linked blacks to their pasts in Africa and in slavery, he wanted for them an Americanizing education patterned after the white Protestants in New England. For that reason, he insisted upon literacy as a condition of extending suffrage rights to blacks. ${ }^{61}$

Immigrants also threatened the republic because crowds of "illiterate peasants, freshly raked in from Irish bogs or Bohemian mines, or Italian robber nests" undermined urban politics and the very security of America's cities. White knew what he wanted, and it surely was not the "slobbering anxiety of pseudo-philanthropists": the new challenges required tough-minded trainers. "It was as ... if a man who finds his child bitten by a rabid dog would not cut out the affected part and cauterize it instantly, but should wash the wound with rose water and coddle the dog with a warm kennel and beefsteaks and insist on giving the cur his liberty." ${ }^{62}$

In 1893 he had the opportunity to have his say about Jews coming out of the East. He had become America's Minister to Russia and in May had received his State Department's cable, asking questions about Jews as potential immigrants. "Representations have been [made] here that Russian Government is about to enforce edict ... which will result in a large migration of destitute people of that class to the United States. If there is foundation for that ... " the Department in Washington stressed, "you will please ascertain and report as speedily as possible terms of the edict and its probable effect." White responded at once with a brief telegram and then set about the task of sending a long dispatch on the subject of "the present condition of Israelites in Russia." A close reading of that dispatch reveals his enlightened reform-minded attitudes towards Talmudic Judaism in the full context of his larger views about Jews in general. ${ }^{63}$ In comparison to what he had read earlier, White now appreciated what he saw with his own eyes: In Russia most of the "vast majority" lived "... in poverty and a very considerable misery, just on the border of starvation." Material circumstances had not changed since the early fifties when, as a young man attached to the Legation, he had traveled seven days "on the outside of a post coach between St. Petersburg and Warsaw." Jews then existed "for the most part in squalor, obliged to resort to almost anything that offers, in order to keep body and soul together. Even the best of them," he recalled, "were then treated with contempt by the lowest of the pure Russians.” 
Now, in 1893, conditions were worse in the smaller towns, "in some of which they form the majority of residents, their poverty is so abject that they drag each other down making frequently a ruinous competition with each other in such branches of business as they are allowed to pursue." In towns of 8,000 to 10,000 Jews could face a sudden demand to make room for another 6,000 ordered into a town from the surrounding countryside. These conditions, combined with a maze of restrictions on occupations, residence patterns, property ownership and transfers, manufacturing activities, and hiring patterns of non-Jews, made life for Jews precarious, and even hazardous given the capricious behavior in the officialdom of the Russian Empire.

This assessment squared with views of others in Europe and America who approached the Jews of Russia from a comparative vantage point that seemed to stress the impact of environment upon behavior. For example, White sounded the classical note on the subject of occupations: "Jews once were an agricultural people. They have been made what they are by ages of persecutions which have driven them into occupations to which they are now so generally devoted." Besides, he explained, claims about Jewish occupational patterns in Russia are often false. There were large numbers of Jewish manual workers in the Empire: in Poland he found a "very large body of artisans," about one-half of the Jewish adult male population. "[A]lmost every brand of manual labor is represented among them, and well represented, as stone masons they have an especially high reputation and it is generally conceded that in sobriety, capacity, and attention to work they fully equal their Christian rivals."

He used a similar approach to other charges leveled against Jews in and out of Russia. No doubt they avoided military service, but who would not, considering the treatment they received in the Russian military. In any event, conscription in 1886 had pulled in some 40,000 Jews. Undoubtedly, Jews did not share the patriotism of Russian enthusiasts: "the wonder is that any human being should expect them to be patriotic." In comparison with Christian lenders and trades people, Jews compared favorably in their dealings with the famous and numerous Russian peasants. But, of course, even though both groups exploited the peasants in Russia, it was the Jew who was singularly targeted as the exploiter of the peasantry. And so far as the charge of antiCzarist activities were concerned, White also stressed environmental pressures. The relatively large proportion of Jews among the "Nihilists" and other underground movements can be accounted for "by the mass of bitterness stored up during ages of oppression not only in Russia but elsewhere."

Invariably, White made comparisons with the western countries in Europe and America, where the number of Jews in the total population 
was in fact quite small. There, the proportion of Jewish wealthy men was significant. There they had acquired respect and influence in important circles of society. Their patriotism and loyalty to crown or state had been demonstrated often. White claimed that he had experienced situations where Jewish members of the German imperial staff had placed patriotism "above all else." He pointed to the Jews in political and financial circles who had "noble" careers in the history of their countries. "And there have been many others, in science, literature, philosophy, the arts," including, he stressed, those in Russia, "in the past and today." In other words, when environmental conditions were not especially hostile to Jews they have "always" shown themselves to be "grateful" to rulers who have "shown a kind regard to them." For that matter, in the United States in the ranks of intellectuals and academics, Jews had also become enthusiastic supporters of the republic and its capitalist economy. At a recent meeting of the American Social Science Association it had been Professor Seligman of Columbia University who had attacked the antisocial forces following the leadership of such men as Ferdinand Lassalle or Karl Marx!

This portion of the report reflected well White's convictions about evolution and the role of education in moving his republican society towards eventual perfection. He identified himself with the Enlightenment of the Protestant West and within that framework had no difficulty in considering the Jews of the Russian Empire as individuals who in time, and with the proper education, would change into the sort of successful and acceptable Jews whom he had come to know in America, Germany, France, and England.

But there was White's other side, the darker one that enlightened reformers often manifested. He excluded American Indians from the beneficial impact of evolution and education; he had serious misgivings about blacks becoming fit citizens without long periods of development; he was convinced that masses of groups of European immigrants arrived with the wrong kinds of social discipline for urban development. Not surprisingly, the anticlerical White rejected Talmudic Judaism as a collective public good on its own terms.

To be sure, after presenting the essence of the Russian government's position on the subject of the Talmud, he seemed at first to take serious exception to it. The Russians, he reported, claim that "Israelites are educated in bitter and undying hate of Christians, and taught not only to despise but to despoil them." Beyond that, Russian officials are convinced that as a result of instructions Jews receive from the Talmud via their rabbis, "and by the simple laws of heredity they have been made beasts of prey with claws and teeth especially sharp, and that the peasant must be protected from them." White categorically rejected these statements. When confronted by passages from the 
Talmud, which he knew was being published in Russia, Western Europe, "and even in the United States," White insisted that it "seemed to be forgotten that the Israelites would be more than human if such passages did not occur in their sacred writings." In the first place, some of the passages antedated Christianity. "Most of them have been the result of fervor under oppression and the appeal to the vengeance of Jehova in time of persecution." Besides it is only fair to compare such passages to "the more kindly passages especially the broadly beautiful humane teachings which are so frequent in the same writings." In Russia, however, reported White, such arguments fall on deaf ears: Russians insisted that they, not outsiders, had the personal experience required for really understanding their Jews. Their relation to Jews, White reported to Washington, was to the Russians what "our own peculiar institution" had once been to Americans, incomprehensible to outsiders who did not live with slavery.

White's apparent rejection obscured his agreement with a critical part of the Russian position. It nestled in policies about the education of Jews. In principle, as a professional American educator, he rejected the quota concepts in admissions policies. So it pained him to see them applied by the Russians. "The world over-as is well known-Israelites will make sacrifices to educate their sons and daughters such as are not made-save in exceptional cases-by other people; they are," he noted, "as is universally recognized, a very gifted race but, no matter how gifted a young Israelite may be, his chances of receiving an education are small." In the Russian context, however, White appreciated Russian fears: in the absence of tight control on admissions of Jews in the high schools, universities, and professional schools, Jews would overrun all these institutions of higher learning.

Nevertheless, White thought those restrictions were counterproductive because it forced Jews to remain in the world of Talmudic education, which, he agreed with the Russians, precluded integration of Jewish life. According to White, the worst feature of the Russian educational system was its insistence that the vast majority of Jews remain in their own schools. "The whole system at present in vogue is calculated to make Talmudic and Theological schools-which are so constantly complained of as the nurseries and hot-beds of anti-Russia and antiChristian fanaticism-the only schools accessible to the great majority of young gifted Israelite." Such a policy did not simply deny Jews access to education, as White understood the meaning of the concept, but locked them into a world that he and the Russians insisted was at the root of the Jewish problem in Russia.

When the Russians told him that they had no hatred of Israelites, only of Talmudic Judaism and its practitioners, they were in effect saying that they wanted their Jews to become radically different. And so 
they pointed to their Karaite Jews who had denied the religious validity of the Talmud: they lived without the detailed rites and rituals and did not lead lives that so differentiated them from non-Jews. Russians told him that they treated the Karaite Jews "with special kindness" because they were not fanatics. White was convinced the Russians had it backwards. The reason Karaite Jews "are free from fanaticism" was because the Russians had treated them kindly for a long time; extend the same kind of treatment to all Jews, he thought, and in time they will also drop their fanaticism. White told Washington that Russia's approach to the Jews was "so illogical as to be incomprehensible" because "great powers are given to the Jewish Rabbis and religious authorities." Russians in fact sustained their fanaticism. "They are allowed, in the districts where the Israelites mainly live to form a sort of state within the state, and with power to impose taxes upon their co-religionists, and to give their regulations virtually the force of law."

White wanted to bring Talmudic Judaism to an end. It was no more acceptable to him than it was to the Russians, albeit as an American Protestant enlightened reformer, he wanted it gone for the sake of his own agenda. Like the Russians, he wanted it eliminated. As a diplomat he wanted only the best for the Russians and for the Israelites. His solution was simple. Rid the Empire of "racial antipathies, remembrances of financial servitude, vague inherited prejudices, with myths and legends like those of the middle ages." Go modern: Substitute "instruction in Science, General Literature and technical branches" which are taught to the Russians for "instruction in the Talmud and Jewish Theology."

Then, in time, the Jews of Russia would become like the Jews of America and Western Europe. There, "invariably those darkest features of the Talmud have been more and more blotted out from Jewish teaching, and the unfortunate side of the Talmudic influence more and more weakened." Obviously, when Jews did not live by the Talmud, "the more bitter utterances in the Talmud complained of do not necessarily lead Israelites to hate Christians." Then they do not live in a state within a state. They become individuals infused with the noblest ideals of the Enlightenment. They become men as Judah Touro in the United States, Sir Moses Montefiore in the United Kingdom, Nathan Rothschild or Baron Hirsch in France, like the less well-known Jews in an American city who raised substantial funds in order to buy relief for anti-Jewish Russians struck by a devastating famine. Or, like the Felix Adler of White's Protestant republican construction. Years earlier, he had publicly defended his appointment of the Jewish Adler as lecturer at Cornell University: "he was a graduate of one of our most renowned Christian colleges, and had been blessed with all the safeguards against error which [Cornell] an institution noted for its orthodoxy could 
throw around him." In other words, without the Talmud and its collective world, Jews would become men and women comparable to the Karaites the Russians appreciated, or a new sort of Jew who White would consider fit for American citizenship and participation in America's civic society.

That development would happen if Russian authorities followed his advice. But he knew they would not do it, and in any event, even if they did the impact of the change on Russian Jewry would be too slow to impact those eager to take flight to a United States increasingly gripped by industrial conflict and what looked like class war. Perhaps that recognition was another reason explaining why White "drained his passion in dispatches to the State Department," to use biographer Glenn Altschuler's insightful phrase, ${ }^{64}$ "instead of battling for change of Russian policy towards Jews." All along he worried that massive Jewish emigration from the Talmudic Kingdom would be full of unskilled illiterates; for skilled, literate, educated better off kinds of Jews, he was convinced, would be organized for migration to Argentina. ${ }^{65}$

Some of the wider ramifications of White's kind of engagement with and hostility toward Talmudic Judaism is best appreciated by turning briefly to contacts he had among influential Reform Jews. As is well known, leaders of the Reform Movement in America were also engaged with and hostile toward Talmudic Judaism. But they were active within the changing People of the Talmud: even as they sought to effect American public policy on behalf of kinsmen in Russia, they dissociated themselves from identifications that would link them to primitives.

The Reform Movements' supporters represented a perspective especially well expressed by the illustrious C. E. Montefiore, a distinguished English scholar who had long fought anti-Jewish prejudice in the circles in which Smith and White traveled. "Pharisaic, Rabbinic, Jewish are adjectives still not infrequently used as synonymous, not only for narrow, intolerant, and obsolete, but also for everything and anything not in New Testament or early Christian literature which the particular writer happens to dislike. All that is noble and good is original and Christian and new; all that is crude or disagreeable is Jewish and Rabbinic and old." He had traveled light years from that Talmudic world, which Enfield and Smith had attacked, and from which Montefiore, within a Jewish framework, separated himself. "I am a Liberal Jew, differing even far more widely than a modern orthodox Jew from 
the religion of the Rabbis; yet my Judaism comes to me through them, and is a development of theirs.... [M] uch of their religious teaching seems to me fine and noteworthy. It contains many 'flowers'.... Some of it, even though we can no longer accept it, is yet striking and beautiful. Some of it is capable of adaptation, enlargement, and purification. Some of it is pathetic, showing the conflict between higher and lower impulses, or revealing a struggle of advancing thought against the bonds of a cruel dogma (namely the perfection and inspired character of every Old Testament utterance), which made progress in certain directions difficult or impossible."

After identifying the constituent and interrelated parts of the Talmud, Montefiore had this to say of the Halakha, the part of the Talmud which Enfield and Smith had selected for attack and derision. The "legal discussions, all this 'study of the Law', all these elaborations and minutiae, were to the Rabbis the breath of their nostrils, their greatest joy and the finest portion of their lives." He thought the "larger part of ... [Halakha] seems a waste of mental energy and of time. If a very big percentage of the halakhik portion of the Rabbinic literature were destroyed, archaeology, comparative jurisprudence would be the poorer, but our modern religious life would hardly be affected. A gulf separates us from the Rabbis, and this gulf has to be recognized. Their most absorbing interests were not ours. We have also to confess that religion meant, and was, more to them than to us. God was nearer to them in more senses than one, and heaven and hell were more definite and influencing realities." In their halakhic mode, he too compared the rabbis "with the men of the medieval world."

When most Jews were still conducting their lives by the light-albeit often flickering-of that Talmud-inspired governance, influential German-American liberal Jews took institutional steps to "distinguish modern Jews from their predecessors by casting off 'excrescences.'” They meant to cut loose from the Jewry's constitutional foundations that which Jefferson, via Enfield, had so misrepresented to Adams. In the closing years of the century, the Central Conference of American Rabbis, without invoking by name the hallowed canon, proclaimed that "our relations in all religious matters are in no way authoritatively, and finally determined by any portion of our Post-Biblical and Patristic literature." For his part, famed banker Jacob Schiff, a traditionally minded Reform Jew, made a practical contribution. As an alternative to Talmudic Judaism, with which the incoming Jew from Russia and Poland had intimate familiarity, and Reform Judaism, which initially seemed so alien to him, Schiff helped finance the revitalization of American Conservative Judaism. In the words of Jonathan Sarna, the reformers who tried to "transform American Jews" in "deeds, if not in words... 
sought to effect changes that would render the modern Jew quite distinct from his pre-modern stereotypical counterpart." They sought to make him "as different from the mythical one as possible."

If only in Americanized fragments and splinters, whatever else was in the core of that mythical Jew, there also nestled Talmudic Judaism and the reputations associated with it. That at least is one conclusion that can be drawn from the evidence presented here. The reformers certainly assumed it about the canon. Themselves part of the changing People of the Talmud, they were especially apprehensive about the capacity of their Jewish opponents to stop or delay among Jews the kindred processes of enlightened rationalism and republican assimilation. In the 1890 s, politically well-connected leaders linked these concerns among important Reform Jews to a specific German-American Jewish agenda. It was calculated to help Jews leave oppressive Russia while taking steps to protect modern Jewish life in America from a kinsman still wed to the classic canon. Concerned about Jewish conditions and needs, Reform Jews, from a deferential posture but more aggressively than in the past, tried to persuade White to alter America's foreign policy dealing with Russian authorities. As this effort involved a larger strategy designed to effect American immigration policy, the German-American Jewish apprehension about being associated with primitive newcomers manifested itself in a special way. ${ }^{68}$ As economic liberals who supported an open door for Caucasians, they joined with other antirestrictionists in opposing Chinese immigration. In their argument they employed the concept of "absolute necessity," the very one that Smith had used in opposing Jewish immigration: Chinese lived in hard-shelled collectives of their own. In their case restriction "may be defended on the grounds of a broad public policy, with reasons which cannot logically be adduced with regard to any branch of the Caucasian race."

In Simon Wolfe's The American Jew as Patriot, Soldier and Citizen, the anthology which published and applauded White's report, Louis Edward Levy developed the argument. Thanks to his abilities as an inventor and entrepreneur, by the 1890s, this son of immigrants, whose Jewish parents had brought him from Bohemia during the last years of the German-Jewish migration before the Civil War, had become a well-known publisher of a Democratic daily in Philadelphia and an influential figure in Jewish circles; ${ }^{69}$ indeed, it was his company that had published The American Jew. He wrote: "the most cogent of the reasons and the one that has afforded the only rational basis for the exclusion policy adopted [by the United States] is not the economic element of the subject, not that Chinese live cheaply and work cheaply, but that their assimilation with the rest of the population is practically impossible." 
But, unlike White, and of course Smith, Levy and other publicly active liberal Jews owned the dynamic patrimony of collectivity from Talmudic Judaism as a dowry, as a kind of natural endowment or gift from old-fashioned forebears. So Levy felt compelled to make the case for accepting bearded Russian Hebrews to America. Such political "or perhaps ultimately ethnological reasons may here be considered as prompting a course which could not reasonably be adopted on any other ground." Even though at the time anthropologists, physicians, and evolutionary biologists, including Jewish ones in Europe and America, were really quite confused about the subject of the Jewish race in Levy's mind Jews conveniently belonged to the Caucasian race. Within that beneficent category opposition to Jews could only rest on economic grounds and these, to a late nineteenth century liberal, were simply unacceptable. ${ }^{70}$

Besides, he was optimistic about the capacity of Polish Jews to change from their folk ways once Russia adopted White's recommendations. America's experience was proof positive: They "have all been assimilated. Those of them that survive, and their children, assuredly have become thoroughly Americanized and effectually welded into the commonality of our Republic." ${ }^{.71}$ He was certain that if the Czar's government adopted policies of enfranchisement and "unhampered domicility" Russia would not only see an end to mass emigration by Jews, but would also witness their transformation into desirable post-Talmudic Jews, like himself. Levy predicted that when such Jews would associate with the Talmud they would become acceptable because it would be a different kind of association than in the past. It would be one dominated by the "great" ideals of Judaism: "the universal fatherhood of God, the universal brotherhood of men, and the direct responsibility for every human being to the Maker of All." ${ }^{, 22}$ At the time, others, perhaps even White, saw such a development as the beginning of the end for all of Jewish life. An English contemporary writer, John Foster Fraser, put the point directly in the Russian context. Should Russia remove the restraint on the Pale, that is, on one-half of the world's Jews, "Judea" would pay a high price indeed: "The last stronghold of Jewish thought and tradition is in Russia. Yet, just as in every country from which he has received freedom the tendency on his own initiative has been to be de-Judaised, the result of emancipation will be that he will become less a Jew and more a Russian, until in time the distinct Jew disappears." Fraser thought this development a public good. He saw "no cause for repining at what the centuries hold in store. Judaism will go; it is going already in every land where the gentiles do not cabin it." 73

This kind of projection did not catch Levy's voice about America's Jewish future from the perspective of segmented post-Talmudic Jews 
in the United States. He and fellow liberal Jews shared many of White's rationalistic anticlerical views about Talmudic Judaism and its rabbinical leadership. However, they also wanted appropriate safeguards within a policy preventing unrestricted mass immigration-appropriate selection screens and training programs applied to those Jewish applicants designated as potentially fit and appropriate for dispersal throughout the American republican body politic-so that migrating Jews would not overwhelm the capacity of the American environment to assimilate them. But liberal Jewish leaders were obviously different from White, who, besides Smith, had other associates who considered it appropriate to share with him their anti-Semitic views about Jews as dangerous creatures conspiring to take over the world.

Levy represented the potential of the right kind of immigrant Jew by reproducing a report from the New York Sun: Last week 10,00012,000 Jewish tailors went on strike, "day after day they loitered in the street or congregated in their hall, or sat down anywhere to talk their jargon. But last Saturday morning the strikers ... were not to be found at their usual places of rendezvous. Nearly all of them had gone to their synagogues where they prayed and listened to the rabbi. They were following a custom established by Moses and kept up through all the ages since his time. In the hundreds of garrets, rear halls, and rickety old edifices which are used as synagogues in what is called the 'ghetto' on the east side of New York, the Jews on strike celebrated the everlasting name of 'JAHVEH' last Saturday forenoon, the holy Sabbath." To the Sun this was "Judaism in New York and the world over." Who ever "heard of any body of strikers other than Jews, giving heed to the ceremonies of their religion during the heat of a strike? We are told that nearly all of these Jewish strikers are orthodox, and all wore their hats in the synagogues. Many of them, we are assured, are familiar with the Torah and the Talmud, and can quote Iben Ezra and Maimonides."74

For Levy this was an American story about the incoming Jew beginning his journey into modern America. A Jew trained with an artisan skill, or a Jew willing and able to labor for his livelihood, and a Jew mentally strong enough to challenge arbitrary authority. Such a Jew was admissible to the societies that White, Levy, and others of his contemporaries were trying to fashion in Europe and America. With White, Levy feared massive Jewish migrations into the United States if the migration consisted of Jews not prepared to participate fully in America's economic and political life. But in a manner akin to the selective screening policy Prussians had been using in finding those Jews in the Dutchy of Poznan, which they had acquired from the Russians in 1815, Levy used economic criteria to support the "correct" kind of Jewish migration. Not surprisingly, he turned to categories of 
occupation or biological fitness for industrial work. Those were the categories neo-Lamarckians were using to argue for or against admission of migrants from the "backward" regions of the world.

Levy was involved with the Jews of Russia as a kinsman eager to perpetuate Judaism in a modern form, one where Jewish association with the Talmud would be transformed in terms of the end-of-thecentury theology and practice of the Central Conference of American Rabbis. Almost all of its members came from the large metropolitan reform congregations that belonged to a German-American Jewry which, in its first and second immigrant generation, was persuading its German-speaking doctrinaire minded rabbis to give way to the needs of more practically minded English-speaking American children. At the congregational level this collective act foreshadowed and facilitated the worshipers' capacity to transform their life with the Talmud. In that light, the story from the Sun may also have suggested to Levy something about the power of rank and file post-Talmudic Jews to change without breaking the relationship to the classic canon in the coming years. To him it was a harbinger of things to come.

Many other German-American Jews also noticed the change, to such an extent, that after the turn of the century they manifested it not only in their congregational life within American liberal Jewry, but in the very theological formulations about ritual conduct derived from the Talmud. In the 1880 s and 1890s, when their views had become entangled with fear of mass immigration, industrial conflict, and emerging Zionism, some rabbinic leaders of the Reform Movement had sounded more like Smith than White: They had railed against "Orientalism," "Talmudism," "Rabbinism," and "Kabbalism.," In 1908, a decade after the desperate days of economic depression, in the midst of the large wave of Jews out of Lithuania, the changes in the rank and file were so manifest that even such a fierce enemy as Rabbi Jacob Voorsanger had to pay attention. He had been to the immigrant's heartland in Manhattan: The "processes of adaptation are already underway. Anyone who compares the Jewish East End of New York of even a decade ago with that of today will discern amazing changes and the unmistakable growth of tendencies in the direction of wholesome and loyal Americanism." ${ }^{76}$ No wonder. Even as White, and those among influential German-American liberal Jews who supported his views, sustained the hostile reputation of the Jewish canon as a primitive medieval fossil, the migration had included growing numbers of post-Talmudic Jews with experience in Central European Jewish anticlerical mass movements of their own. Some had started to emerge as innovative leaders in urban trade unionism and politics. In his popular Yiddish-language anticlerical daily Forward, immigrant Abe Cahan would symbolically identify them with a cartoon in which Uncle Sam 
welcomes a hatless, beardless, clean shaven, and suit-dressed Socialist Meyer London to Congress: "Hello! Really A New Sort of Jew-I like you." By 1908 that nineteenth century Uncle had good reason. Jews neglected formal Jewish education, transformed the Shabbes, and with all sorts of references and allusion to Talmudic rules and rituals celebrated America's urban secular Stadtluft in Americanized Yiddish song and theater. ${ }^{7}$

All had been caught up, to quote Hall once again, in a "muddied, multilayered process ... [that] functioned to preserve and pass along many bits and pieces of past systems of belief." In the United States that had meant Jewish heads and practices were full of meaningful debris. The incoming Jews' engagement with Talmudic Judaism was being transformed, but its fragments and splinters from an earlier era were in the woof and warp of the new kind of Jewish identity establishing itself among Americas' post-Talmudic Jews. In their masses they were holding onto parts of their patrimony without being overwhelmed by the tribal fires of modernity which theoretically minded fellow Jews had lighted in liberal synagogues, in social-democratic trade unions and newspapers, or in revolutionary sects. By World War I, Talmudanchored rituals had started to become part of the leading congregations in the Reform Movement. A revitalized Conservative Movement organized around the mass participation of post-Talmudic Jews. Henry Adams had been correct about New York's Lower East Side: it was still full of kosher butcher shops, ritual baths, synagogues, and the High Holy days were celebrated in specially rented halls full of worshippers. And, as trade unionists, socialists, and Zionists post-Talmudic secularizing Jews were helping to give shape to an emerging American Jewish ethnicity. ${ }^{78}$

What then of the hostile features in the Talmud focused reputation of Jews in the Promised Land? In this exploratory effort, it is premature to answer comprehensively. But in a post-Shoa world, it is not premature to offer a closing thought to this work in progress. The evidence from the nineteenth and early twentieth centuries may be read as the Judeo-phobic part of a larger and deadly bio-cultural driven obsession in the United States. It had expressed itself in a sustained effort that distinguished between primitive and civilized, between tribal and modern. $^{79}$

CORNELL UNIVERSITY

1. More than forty years ago, as a student of New England's fragmenting Puritan tradition, the eminent Perry Miller offered helpful insights for compre- 
hending complexities of this sort when he wrote about individualism and collectivism in Anglo-American history. He distinguished between the Puritan's "theocratic" and "psychological" engagements with New England. Miller's theocratic engagement was a fixed condition resulting in John Winthrop's kind of reading of the errand by light of his Scripture. The psychological one engaged the settlers with daily opportunities among strangers and neighbors. It held out the promise of immediate and continuous success in land acquisition, merchant enterprise, or illicit fornication. Errand into the Wilderness (Cambridge, 1956), pp. 16-18. On the "Land of Promise" and "Promised Land," in England and Puritan Massachusetts during the 16th and 17th centuries, see the following. John Cotton, B. D. "Gods promise to his plantation, 2 Sam. 7. 10" in sermon [Anr. ed] W. Jones, F. J. Bellamy, 1634 in Microfilm; "The Epistle of St. Paul Unto the Hebrews" in Tyndales New Testament, ed. David Daniell, Trans. from the Greek by William Tyndale in 1534, (New Haven, 1988); Daniell to Gerd Korman, 13 April 1994 where Daniell says about Deuteronomy IX/ 28: "Tyndale's 'the land which he promised them' did not occur in English before him.... The Vulgate has 'in terram, quam pollicitus est eis.' Whether Tyndale's translation reached America apart from the Geneva Bible is so far unknown, but in this case it doesn't matter because Geneva simply reprints Tyndale"; Rivkah Zim, English Metrical Psalms: Poetry and Praise and Prayer, 1535-1601 (Cambridge, 1987); G. F. Waller, Mary Sidney, Countess of Pembroke: A Critical Study of her Writings and Literary Milieu (Salzburg, 1979), pp. 170, 182-186; Robert. L. Wilken, The Land Called Holy: Palestine in Christian History and Thought (New Haven, 1992), pp. 53; John Milton, Paradise Lost, Book 12 Line 172 and Paradise Regained, Book 3, Line 531 (New York, 1936); Moshe Weidenfeld, The Promise of the Land, Inheritance of the Land of Canaan by the Israelites (Berkeley, 1993), passim; Sydney E. Ahlstrom, A Religious History of the American People (New Haven, 1972), pp. 135-384; Sacvan Bercovitch, "Puritan New England Rhetoric and the Jewish Problem," Early American Literature, Vol. 5, No. 2 (1970-1971), pp. 63-71, Puritan Origins of the American Self (New Haven, 1975), passim; Loren Baritz, City on a Hill; A History of Ideas and Myths in America (New York, 1964), pp. 3-44. See also the following dictionaries for the concept of "promise": Robert Young, Analytical Concordance to the Bible (New York, 1893); James Hastings, et al., eds., A Dictionary to the Bible, (New York, 1903).

2. Eli Faber, A Time of Planting: The First Migration 1654-1820 (Baltimore, 1992), pp. 127-134.

3. In his battle with Karaites, R. Saadia Gaon (A.D. 882-942) used "Am Ha Torah" to designate Rabbanite Jewry, which was making the Talmudic corpus its governing source. R. Saadia "strongly held that the Jews were a people only through the Torah and hence the leadership should be vested in a man who had the authority to interpret the Torah [omtehnu ehnena omah ki am betorahtehnu]." Solomon Zeitlin, "Saadia Gaon-Champion for Jewish Unity Under Religious Leadership," in Saadia Studies (Philadelphia, 1943), pp. 397. See also Henry Malter, Saadia Gaon His Life and Works (Philadelphia, 1942), pp. 157; H. H. Ben-Sasson, et al., A History of the Jewish People (Cambridge, 1976), pp. 443-461; Moshe Halbertal, People of the Book: Canon, Meaning, and Authority (Cambridge, 1997), pp. 9, 16-17, 58; Norman A. Stillman, The Jews of 
Arab Lands: A History and Source Book (Philadelphia, 1979), pp. xv, 31-39, 4748, 52, 60-61, 189-191, 198-199, 208-210, 269-270; Gavin I. Langmuir, History, Religion, and Anti-Semitism (Berkeley, 1990), pp. 295-297; Jacob Katz, "Post-Zoharic Relations Between Halakhah and Kabbalah," and Isadore Twersky, "Talmudists, Philosophers, Kabbalists: The Quest for Spirituality in the Sixteenth Century," in Jewish Thought in the Sixteenth Century, Texts and Studies/ Harvard University Center for Jewish Studies, ed. Bernard Dov Cooperman (Cambridge, 1983), II: pp. 283-307, 431-457.

4. Leonard Dinnerstein, Uneasy at Home: Anti-Semitism and the American Jewish Experience (New York, 1987), pp. 1-7; David A. Gerber, "Introduction," and Jonathan D. Sarna, "The 'Mythical Jew' and the 'Jew Next Door' in Nineteenth Century America," in Anti-Semitism in American History, ed. Gerber (Urbana, 1986), pp. 1-38, 57-58; Henry F. Feingold, ed., The Jewish People in America, 5 vols. (Baltimore, 1992); Ben-Sasson, et al., History of the Jewish People, pp. 790-833, 859-869; Halbertal, People of the Book, pp. 128-129; Jacob Katz, Out of the Ghetto: The Social Background of Jewish Emancipation 1770-1870 (New York, 1973); Uriel Tal, Christians and Jews in Germany: Religion, Politics, and Ideology in the Second Reich, 1870-1914 (Ithaca, 1975); Alan L. Mittleman, The Politics of Torah: The Jewish Political Tradition and the Founding of Agudat Israel (Albany, 1996); Mordechai Breuer, Juedische Orthodoxie Im Deutschen Reich 1871-1918 (Frankfurt am Main, 1986); Steven E. Ascheim, Brothers and Strangers: The East European Jew in German and German Jewish Consciousness, 18001923 (Madison, 1982); Robert S. Wistich, The Jews of Vienna in the Age of Franz Joseph (Oxford, 1989); Jonathan Fraenkel, Prophecy and Politics (New York, 1981).

5. I am grateful to Arthur A. Goren, Jeffrey S. Gurock, and Jonathan Sarna for confirming this reading of the professional literature about the Talmud. Except for the many old and new studies elucidating classical rabbinical texts in the tradition of Ephraim Urbach, and studies of theology and religious institutional development in the manner of Jeffrey Gurock, Michael A. Meyer, and Jonathan Sarna there is no body of historical literature about the Talmud and American life that in any way compares to the corpus of books and articles historians have written about Jews and European society. See the "Talmud" entries in Robert Singerman, Anti-Semitic Propaganda: An Annotated Bibliography and Research Guide (New York, 1982) and in his Judaica American: A Bibliography of Publication to 1900, 2 vols. (West Port, 1990). Historians have written about such subjects as the place of the Talmud in educational institutions, including the United States Army during its occupation of Germany after WWII. See, for example, Paul Ritterband, Jewish Learning in American Universities: The First Century (Bloomington, 1994); Shuly R. Schwartz, The Emergence of Jewish Scholarship in America: The Publication of the Jewish Encyclopedia (Cincinnati, 1991); Gerd Korman, "Survivors' Talmud and the U.S. Army," American Jewish History, Vol. 73, No. 1 (March, 1984), pp. 252-285; Norma Baumel Joseph, "Jewish Education for Women: Rabbi Moshe Feinstein's Map of America," American Jewish History, Vol. 83, No. 2 (June, 1995), pp. 205-222 and Jeffrey S. Gurock, "Resisters and Accommodators: Varieties of Orthodox Rabbis in America, 1886-1983," American Jewish Archives, Vol. 35 (November, 1983), pp. 100-187. For some recent examples of more general historical studies of American reli- 
gion see Sydney E. Ahlstrom, A Religious History of the American People (New Haven, 1972), pp. 569-582, 967-984, 1130, 1155; R. Laurence Moore, Religious Outsiders and the Making of Americans (New York, 1986), pp. 72-101; George M. Marsden, Religion and American Culture (New York, 1990), pp. 142147, 219-224. Ahlstrom, who does not index "Talmud," on p. 571 explains that "By $500 \mathrm{CE}$ the huge Babylonian Talmud had taken definitive shape: the nature and rationale of Jewish isolationism and continuity were defined" and that subsequently "Judaism became more than ever a way of life according to the meticulously interpreted and rigorously applied provisions of the Torah." On p. 971 he says about Jewish Orthodoxy, until the end of the nineteenth century in the Russian Empire, "Here, where the gentile world did not intrude on Torah-centered living, the Sabbath could truly be a foretaste of heaven. The old system of nurture assured the raising up of new students of the Scriptures, the Talmud, and the rabbinic commentaries." But for American religious history, the subject of his book, the Talmud is all but irrelevant for his understanding of religious history. Moore does index "Talmud," but the references are to passing remarks involving Reform Jews (p. 78) and the transfer of training in upward mobility (pp. 86-87). Marsden ignores the Talmud altogether.

6. Sarna, "The 'Mythical Jew' and the 'Jew Next Door' in Nineteenth Century America," in Gerber, Anti-Semitism in American History, pp. 57-78. On Sarna's place in contemporary American Jewish historiography see Gerber, AntiSemitism in American History, pp. 9-12.

7. For a provocative hypothesis about the legacy of the "Third Reformation" of refugee Protestants and tolerance of Jews see Heiko A. Oberman, "Three Sixtenth Century Attitudes to Judaism: Reuchlin, Erasmus and Luther," in Jewish Thought in the Sixteenth Century, ed. Cooperman, p. 351.

8. Jonathan Frankel, The Damascus Affair: "Ritual Murder," Politics, and the Jews in 1840 (New York, 1997), pp. 259, 439-445.

9. David S. Katz, The Jews in the History of England 1485-1850 (Oxford, 1996), p. 108.

10. George L. Mosse, "Jewish Emancipation: Between Bildung and Respectability," Michael A. Meyer, "Reform Jewish Thinkers and Their German Intellectual Context," Jacob Katz, "German Culture and the Jews," David Sorkin, "The Invisible Community: Emancipation, Secular Culture, and Jewish Identity in the Writings of Berthold Auerbach," Shulamit Volkoff, "The Dynamics of Dissimilation: Ostjuden and German Jews," and Steven E. Ascheim, "The Jew Within: The Myth of 'Judaization' in Germany," in The Jewish Response to German Culture: From Enlightenment to the Second World War, ed. Jehuda Reinharz and Walter Schatzberg (Hanover, 1985), pp. 1-16, 64-119, 195-241.

11. Mosse, Toward the Final Solution: A History of European Racism (New York, 1978), pp. 138-141; Tal, Christians and Jews in Germany, pp. 62, $75 \mathrm{n}$. 78; Richard J. Evans, Death in Hamburg: Society and Politics in the Cholera Years 1830-1910 (New York, 1990), pp. 256-372; Howard Markel, Quarantine!: East European Jewish Immigrants and the New York City Epidemics of 1892 (Baltimore, 1997).

12. New York Review of Books, December, 16, 1999, p. 26.

13. Increase Mather, The Mysterie of Israel's Salvation Explained and Applied: On a Discourse Concerning the General Conversion of the Israelitish Nation ... (Lon- 
don, 1669), pp. 15, 16 for comments on "Rabbis" and "Talmudic Jews." See also his A Dissertation Concerning the Future Conversion of the Jewish Nation. Answering the Objections of the Reverend Mr. Baxter, Dr. Lightfoot, and others. With an Enquiry into the First Resurrection. (London, 1709), and his "The Preface to the Reader" (1722) published as part of R. Judah Monis treatises, Three Discourses ... The Truth, the Whole Truth, and Nothing but the Truth. One of Which was Delivered by him at his Baptism (Boston, 1722). My reading of Increase Mather has benefited from a stimulating paper on Mysterie by Joshua Perry, "The Meaning of Mystery: Increase Mather's Eschatology of Ambiguity and Development," a Junior Essay submitted to Professor Sacvan Bercovitch at Harvard University, January 7, 1999.

14. On Cotton Mather see the following: Ronald Takaki, "The Tempest in the Wilderness: The Racialization of Savagery," Journal of American History, Vol. 79, No. 3 (December, 1992), p. 909; Jill Leopora, The Name of War (New York, 1999), pp. 173-182; Richard Slotkin, The Fatal Environment (Middletown, 1985), pp. 56-63. For a larger Euro-American context of wars between New England Puritans and Native Americans see Ronald Dale Carr, "Why Should You Be So Furious?': The Violence of the Pequot War," Journal of American History, Vol. 85, No. 3 (December, 1998), pp. 859-909.

15. John Carey, The Intellectuals and the Masses: Pride and Prejudice among the Literary Intelligentsia 1880-1939 (New York, 1992); H. J. Dyos, Victorian Suburb (Leicester, 1966); Asa Briggs, Victorian Cities (London, 1963), pp. 168-234; Paul Boyer, Urban Masses and Moral Order in America 1870-1920 (Harvard, 1978), pp. 123-283; Joel Williamson, "Wounds Not Scars: Lynching, the National Conscience, and the American Historian," Journal of American History Vol. 84, No. 4 (March, 1997), pp. 1236-1238; Leon F. Litwack, Trouble in Mind: Black Southerners in the Age of Jim Crow (New York, 1998), pp. 179-325. For biological determinisms in Europe and America, in particular neo-Lamarckism between the American Civil War and World War I, see the following: Yosef Hayim Yerushalmi, Freud's Moses: Judaism Terminable and Interminable (New Haven, 1991) pp. 32-33; John Efron, Defenders of the Race: Jewish Doctors $\mathcal{E}$ Race Science in Fin De Siecle Europe (New Haven, 1994), pp. 6-27 and passim; Sander L. Gilman, The Case of Sigmund Freud: Medicine and Identity at the Fin De Siecle (Baltimore, 1993), pp. 11-20; Eric L. Goldstein, " 'Different Blood Flows in Our Veins': Race and Jewish Self-Definition in Late Nineteenth Century America," American Jewish History, Vol. 85, No. 1 (March, 1997), pp. 29-55; Peter J. Bowler, The Eclipse of Darwinism (Baltimore, 1983), pp. 3-140, Evolution: The History of an Idea (Berkeley, 1984), pp. 233-274, 282-290; Ernst Mayr, The Growth of Biological Thought: Diversity, Evolution and Inheritance (Cambridge, 1982), pp. 356-357; Mosse, Toward the Final Solution, p. 18. Neo-Lamarckism had its own national contexts. For the United States see George W. Stocking, Jr., Race, Culture, and Evolution: Essays in the History of Anthropology (New York, 1968), pp. 234-269. A brief recent comparative perspective is in Frank Dikoetter, "Race Culture: Recent Perspectives on the History of Eugenics," American Historical Review, Vol. 103, No. 2 (April, 1998), pp. 467-478.

16. Arthur A. Goren, "Preaching American Jewish History: A Review Essay," American Jewish History, Vol. 79, No. 3 (September, 1990), pp. 542-547; 
Jacob Rader Marcus, United States Jewry, 1776-1985 (Detroit, 1991-1993), II, p. 264, III, pp. 75, 137-138, 419, 510-511, 516, 523, 592, 610, 620-630, 639640; Faber, A Time for Planting, pp. 52-126; Hasi Diner, A Time for Gathering: The Second Migration 1820-1880 (Baltimore, 1992), pp. 86-100, 114-141, 203230; Gerald Sorin, A Time for Building: The Third Migration, 1880-1920 (Baltimore, 1992), pp. 77, 80, 94, 96-97, 170-190; Jeffrey S. Gurock, American Jewish Orthodoxie in Historical Perspective (New York, 1996), pp. 63-90, 353 n. 3, 386 n. 4, 389 n. 25, 391 n. 40; Avraham Barkai, Branching Out: German-Jewish Immigration to the United States, 1820-1914 (New York, 1994); editorials and articles published in the American Israelite between 1882 and 1885; C. G. Montefiore and H. Lowe, eds., A Rabbinic Anthology (New York, 1974), pp. xvii, xciii-xcviii. See also Ephraim E. Urbach, The Sages: Their Concepts and Beliefs (Jerusalem, 1975), I, pp. 524-648; David Landau, Piety and Power: The World of Jewish Fundamentalism (New York, 1993), pp. 175-182.

17. David D. Hall, Worlds of Wonder, Days of Judgement: Popular Belief in Early New England (Cambridge, 1990), p. 11. Michael A. Meyer has expressed comparable judgements about German Jewry during the first half of the nineteenth century. Michael Brenner, Stefi Jersch-Wenzel, Michael A. Meyer, Emancipation and Acculturation, 1780-1871. Vol. 2, German-Jewish History in Modern Times, ed. Michael A. Meyer and Michael Brenner (New York, 1997), pp. 90-97.

18. In choosing these designators I have been influenced by Isaac M. Wise and Peter Gay. In his American Israelite Wise used the unusual terms of "PreTalmudic, Talmudical, and Post-Talmudical literatures" in making discrete designations within the classic corpus. Reminiscences (Cincinnati, 1901), pp. 313321; the American Israelite, August 4, 11, 1882, February 20, 1885; Gay examined the tension between paganism and Christianity in his The Enlightenment, An Interpretation (New York, 1966-1969). See also Stillman, Jews of Arab Lands, p. 31.

19. Gordon S. Wood, The Radicalism of the American Revolution (New York, 1993), pp. 191-192, 328-336, 366-367.

20. Frank E. Manuel, Broken Staff: Judaism through Christian Eyes (Cambridge, 1992), pp. 4, 6-7, 10-11, 191; Jacob Katz, From Prejudice to Destruction, pp. 21-47. See Katz, The Jews in the History of England, pp. 110-114 for the place of Hebrew, the Kabala, and individual Jews in the role of philo-Semites in the ranks of Judaizers and millennarians in England in the sixteenth and seventeenth centuries, and pp. 371-382, for the year between the end of the eighteenth century and the first decades of the nineteenth; Frank E. Manuel, "Israel and the Enlightenment," Daedalus, 111 (Winter, 1982), pp. 33-51; Allan Arkush, "Voltaire on Judaism and Christianity," American Jewish Studies Review, Vol. 18, No. 2 (1993), pp. 223-243; David Brian Davis, "Jews and Blacks in America," New York Review of Books, December 2, 1999, pp. 58; Arthur Hertzberg, The French Enlightenment and the Jews (NewYork, 1968).

21. Robert W. Healey, "Jefferson on Judaism and the Jews: 'Divided We Stand, United We Fall!' " American Jewish History, Vol. 73, No. 2 (June, 1984), pp. 359-374. For an example of the context of the passages Jefferson quoted, see William Enfield, The History of Philosophy... (London, 1791) Vol. 2, pp. 189, 208-209. 
22. Adams to F. A. Vanderkemp in 1809 as quoted in Baritz, City on a Hill, p. 147.

23. Editor Lester J. Cappon, The Adams-Jefferson Letters: The Complete Correspondence Between Thomas Jefferson and Abigail and John Adams (New York, 1971), pp. 340-345, 361-362, and 382 where Adams is convinced that Septuagint was known to many a Greek and Roman and also suspects that Hebrews learned from Babylon, Egypt, and Persia.

24. Adams-Jefferson Letters, pp. 326, 327, 333-334, 337, 343, 361-363; Dumas Malone, Jefferson and his Time, 6 vols. (Boston, 1970), III, pp. 448-500, IV, pp. 200-205.

25. On Priestley see Katz, Jews in the History of England, pp. 296-300 and these publications of Priestley: An inquiry into the knowledge of the ancient hebrews, concerning a future state (London, 1801); Letters to the Jews, inviting them to an amicable discussion of the evidence of Christianity (New York, 1794); and A comparison of the institutions of Moses with those of the Hindoos and other ancient nations; with remarks on Mr. Dupuis's Origin of all religions, the laws and institutions of Moses methodized, and an address to the Jews on the present state of the world and the prophecies relating to it. (Northumberland, 1799). In those years the mix of race and religion, in controversies about slavery and divorce in scriptural texts, further complicated perceptions of Hebrews. David Davis, The Problem of Slavery in the Age of Revolution 1770-1823 (Ithaca, 1975), pp. 536-556.

26. T. H. Breen, "Ideology and Nationalism on the Eve of the American Revolution: Revisions Once More in Need of Revising," Journal of American History, Vol. 84, No. 1 (June, 1997), pp. 15-16; Katz, Jews in the History of England, pp. 254-259.

27. Katz, The Jews in the History of England, pp. 296-300, 361.

28. David Levi, Letters to Dr. Priestley, In Answer to the Addressed to the Jews; Inviting Them to An Amicable Discussion Of the Evidences... (New York, 1794 [First American Edition From the Second British Editions]); Levi, A Defense of the Old Testament in a Series of Letters Addressed to Thomas Paine (Philadelphia, 1798), pp. 22, 67, 74, 76, 85, 106, 118-119, 142, 151, 152, 153, 181.

29. Katz, Jews in the History of England, p. 300.

30. Adams-Jefferson Letters, pp. 426-429.

31. Ibid., pp. 468-469.

32. Ibid., p. 383.

33. Ibid., pp. 396-397.

34. Ibid., pp. 380-383.

35. Wise, Reminiscences, pp. 272-273. On recent articles on missionaries, sans Talmud, see Sarna, "The Impact of Nineteenth Century Christian Missions on American Jews," and Gurock "Jewish Communal Divisiveness in Response to Christian Influences on the Lower East Side, 1900-1910," in Jewish Apostasy in the Modern World, ed. Todd Endelman (New York, 1987), pp. 232-271. For some examples of historians' references to or quotations of attacks on the Talmud see Dinnerstein, Anti-Semitism, p. 28; Sarna, Jacksonian Jew, pp. 139, 296, and Jewish Publication Society: The Americanization of Jewish Culture, 1888-1988 (Philadelphia, 1989), pp. 58, 159, 309; Michael N. Dobkowski, The Tarnished Dream: The Basis of American Anti-Semitism (New York, 1979), pp. 23-24, 27-28, 
31-32 and Frederic Cople Jaher, A Scapegoat in the New Wilderness: the Origins and Rise of Anti-Semitism in America (Cambridge, 1994), pp. 154, 161, 219.

36. New York Herald quoted in Jaher, Scapegoat, p. 219; Proceedings of the American Jewish Historical Society, Vol. 8 (1900), pp. 141-142; Joseph Jacobs, "The Damascus Affair of 1840 and the Jews in America," Proceedings of the American Jewish Historical Society, Vol. 10 (1902), pp. 119-128; Oscar Handlin, Boston's Immigrants (Cambridge, 1974), pp. 164, 170; Jeremiah Berman, "The Trend in Jewish Religious Observation in Mid-Nineteenth Century America," Publications of the American Jewish Historical Society, Vol. 37 (1947), pp. 31-53; Jonathan Sarna, "The Jews of Boston in Historical Perspective," Ellen Smith, "Israelites in Boston, 1840-1880," Gerald H. Gamm, "In Search of Suburbs: Boston's Jewish Districts, 1843-1994," David Kaufman, "Temples in the American Athens," Susan Ebert, "Community and Philanthropy," all in The Jews of Boston, ed. Sarna and Ellen Smith (Boston, 1995), pp. 5-6, 9, 49-67, 132-134, 168-175, 212-215; Diner, A Time for Gathering, pp. 143, 153, 275 n. 32.

37. Sol Liptzin, The Jew in American Literature (New York, 1966); Louis Harap, The Image of the Jew in American Literature (Philadelphia, 1974), pp. 9395, 101-104, 184.

38. Melman, The History of the Jews, 3 vols. (London, 1866), I, pp. 6, 39, 40, 42; Walter Harding, Emerson's Library (Charlottesville, 1967), p. 190.

39. Baritz, City on a Hill, pp. 222-223.

40. Robert J. Lowenberg, An American Idol: Emerson and the Jewish Idea (New York, 1984), pp. 34-35, 79-81, 83-85. Lowenberg explicitly identifies Emerson's thinking about Jews with the passages Jefferson had selected from Enfield when he quoted it to John Adams.

41. For Emerson's passages see William H. Gilman and Alfred R. Ferguson, eds., The Journals and Miscellaneous Notebooks of Ralph Waldo Emerson (Cambridge, 1960), IV, p. 181, VII, pp. 221-222, 321, 350, 400, and n. 643, XIII, p. 120, XV, pp. 438-439, XVI, pp.175; by Joseph Slater et al., eds., Collected Works of Ralph Waldo Emerson (Cambridge, 1979), II, p. 45I, IV, pp. 75-76, V, pp. 26, 121-130; by Ralph J. Rusk, ed., The Letters of Ralph Waldo Emerson (New York, 1939), II (1836-1841); The Dial, I-IV (1840-1844); Stephen E. Whicher, ed., Selections from Ralph Waldo Emerson (Cambridge, 1960), pp. 336-337, 345. See also Philip L. Nicoloff, Emerson on Race and History (New York, 1961), pp. 112 $113,118 \mathrm{ff}$.

42. Lowenberg, An American Idol, p. 34; William H. Gerdts and Theodore Stebbins, Jr., "A Man of Genius," The Art of Washington Allston, 1779-1843 (Boston, 1979), pp. 102-109, 161; David Bjelajac, Millenial Desire and the Apocalyptic Vision of Washington Allston (Washington DC, 1988), pp. 114, 182, 185-187, and Washington Allston, Secret Societies and the Alchemy of Anglo-American Painting (New York, 1997), pp. $101 \mathrm{ff}$. One of the paintings, an oil on canvas, is in the Corcoran Gallery of Art in Washington DC.

43. Emerson, Journals, VII, pp. 321, 350, XIII, p. 120, XVI, p. 175, XV, pp. 438-439.

44. Mayr, The Growth of Biological Thought, pp. 356-357; Peter J. Bowler, The Eclipse of Darwinism (Baltimore, 1992), pp. 3-140, Evolution: The History of an Idea, (Berkeley, 1984), pp. 233-274, 282-290; Stocking, Race, Culture, and 
Evolution, p. 238. For examples of biological determinisms in earlier contexts and public health paradigms see C. Zirkle, "The Early History of the Idea of Inheritance of Acquired Characteristics and of Pangenesis," Transactions of the American Philosophical Society, Vol. 35, No. 5 (1945), p. 91-151; John Block Friedman, The Monstrous Races in Medieval Art and Thought (Cambridge, 1981), pp. 31-32, 54-55, 69, 88; Davyd Greenwood, Nature, Culture, and Human History: A Bio-Cultural Introduction to Anthropology (New York, 1977), pp. 38-41, 107-126; B. Netanyahu, The Origin of the Inquisition in Fifteenth Century Spain (New York, 1995), pp. 1082-1084, 1145; Henry Kamen, "The Secret of the Inquisition," New York Review of Books, February 1, 1996, pp. 4-6; Carlo Cipolla, Miasmas and Disease: Public Health $\mathcal{E}$ the Environment in the Pre-Industrial Age (Yale, 1992), pp. 4-5; Mosse, Toward the Final Solution, pp. 18, 138-141; Efron, Defenders of the Race, pp. 7-27 and passim; Bowler, Evolution, pp. 243-256.

45. Yerushalmi, Freud's Moses, p. 31.

46. This was particularly true of doctors who were convinced of significant connections between mental illness and sexual practices. Efron, Defenders of the Race, pp. 6-7.

47. Gilman, The Case of Sigmund Freud, pp. 11-20. For other kinds of examples of connections between biological concepts and Jewish practices see Thomas Schlich, "The Word of God and the Word of Science and Jewish Dietary Laws in Germany, 1820-1920," in The Science and Culture of Nutrition, 1840-1940, ed. Hamke Kamminga and Andrew Cunningham, (Amsterdam, 1995), pp. 97-128, "Medicalization and Secularization: The Jewish Ritual Bath as a Problem of Hygiene (Germany 1820s-1840s)," Social History of Medicine, Vol. 7, No. 3 (December, 1995), pp. 423-442.

48. Glenn C. Altschuler, Andrew D. White-Educator, Historian, Diplomat (Ithaca, 1979), pp. 85, 101, 167, 201.

49. Gerald Tulchinsky, "Goldwin Smith: Victorian liberal anti-Semite," The Whig Standard Magazine, (September 22, 1990), pp. 4-6; Steven G. Bayme, "Jewish Leadership and Anti-Semitism in Britain," Ph.D. Dissertation, (Columbia University, 1977), pp. 120-128; Colin Holmes, "Goldwin Smith," Patterns of Prejudice, Vol. 6 (September-October, 1972), pp. 25-30; Dobkowski, Tarnished Dream, p.187; Goldwin Smith, "Can Jews Be Patriots," Nineteenth Century, Vol. 3 (May, 1878), pp. 875-887. The quotations are on pp. 875-876. The article was in response to Rabbi Herman Adler's "Can Jews Be Patriots," ibid., April, pp. 637-643 where Adler refers to Smith's attitudes about Jews and English foreign policy.

50. James Laister, "Why are Jews Persecuted," Modern Thought, Vol. 4 (1882), pp. 145-51, 183-192; Vol. 5 (1883), pp. 529-36; Laister to Smith, 16 December 1881 in Goldwin Smith Papers available at Cornell University Archives where they are stored on microfilm reels, organized by date.

51. Ibid., 16 December 1881.

52. Ibid., 19 May, 6 November 1882.

53. H. M. Hyndman, "The Dawn of a Revolutionary Epoch," Nineteenth Century, Vol. 9 (January, 1881), pp. 1-18; the quotation is on pp. 10-11.

54. Goldwin Smith Papers, 22 February 1882; Nineteenth Century, Vol. 10 (October, 1881), pp. 501, 511-512. See also Smith's "New Light on the Jewish Question," North American Review, Vol. 152 (August, 1891), pp. 129-143. 
55. Nineteenth Century, Vol. 10, pp. 495-496.

56. Ibid., p. 510.

57. Robert S. Wistrich, Anti-Semitism: The Longest Hatred (New York, 1992), p. 117; Gerber, Anti-Semitism in American History, pp. 30-31, 50-51, n. 87, 88; Ernest Samuel, Henry Adams: The Middle Years (Cambridge, 1958), p. 168, The Major Phase (Cambridge, 1964), pp. 130-131, 243, 255, 356-357, Henry Adams (Cambridge, 1989), pp. 97-98, 315, 320; J. C. Levenson, The Mind and Art of Henry Adams (Boston, 1957), pp. 224-228, 354; Henry Adams [Francis Snow Compton], Esther (New York, 1938 [New York, 1884]), pp. ix, 2, 17, 28, 125; editor Worthington Chauncy Ford, Letters of Henry Adams, 1858-1918, 2 vols. (Boston, 1930-38), I, p. 388, II, p. 620; Edward Chalfant, Better in Darkness: A Biography of Henry Adams, His Second Life, 1862-1891 (Hamden, 1994), pp. 391, $800-1$, n. 35 .

58. Harold Dean Carter, Henry Adams and his Friends (Boston, 1947), p. 583.

59. Altschuler, White, p. 29, 232, 238-239, 247.

60. Ibid., p. 29, and White to Roosevelt, 15 August 1902 in ibid., p. 259.

61. Ibid., pp. 54-55, 78, 184.

62. Ibid., pp. 53-58, 184-185, 189. The quotation is on pp. 184-185.

63. Except as otherwise noted, these and other cited dispatches are in the A. D. White Collection at Cornell University, where they are available on microfilm reels, organized by dates: 14, 21 November 1892; 9 March 1893. See also Altschuler, White, p. 195.

64. Altschuler, White, pp. 98, 196. In Adler's case, notwithstanding White's kind of defense, Cornell eased him out anyway.

65. Ibid., pp. 195-197.

66. Montefiore and Lowe, A Rabbinic Anthology, pp. xvi-xvii, xxii. Sarna points to the overlap between the work of the Jewish Publication Society, heir to "Wissenschaft das Judentums," with German currents in the emerging American profession of history. White, like his colleague and occasional correspondent at Johns Hopkins, Herbert Baxter Adams, was involved in these currents which expressed themselves in the publications committee of the JPS before the turn of the century. Jewish Publication Society, p. 57.

67. Gerber, Anti-Semitism in American History, pp. 69-74. On this entire approach see Marcus, United States Jewry, III, pp. 75: “... like the Deists, the American Jewish liberals tended to downgrade the Talmud and some of its teachings and upgrade the veneration of the Bible. Binding authority was denied to post biblical writings and rituals; the spirit is eternal but the forms are changeable."

68. Altschuler, White, pp. 195-197; Sorin, A Time for Building, pp. 170-214; Barkai, Branching Out, pp. 196-206; Markles, Quarantine, passim, but especially pp. $148-152$.

69. Dictionary of American Biography, Vol. 11, pp. 202-203.

70. Louise Edward Levy, "The Russian Jewish Refugee in America," in American Jew as Patriot, Simon Wolfe (Philadelphia, 1895), pp. 551-552. Levy first read this paper to the Board of Presidents of National Societies of Philadelphia, of which he was a member. White's report is in American Jew as Patriot, pp. 527-540. 
71. Ibid., pp. 556-557.

72. Ibid., p. 565.

73. John Foster Fraser, The Conquering Jew (London, 1915), p. 217.

74. Wolfe, American Jew, pp. 563-564.

75. Alan Silverstein, Alternatives to Assimilation: The Response of Reform Judaism to American Culture 1840-1930 (Hanover, 1994).

76. Ibid., p. 119.

77. Forward, 13 November 1914; Fred Somkin, “Zion's Harp By the East River: Jewish American Popular Songs In Columbus's Golden Land, 18901914," Perspectives in American History, New Series 2 (1985), pp. 183-220.

78. Sorin, Time for Building, p. 175; The Jewish Encyclopedia, XII (1905, 1909, 1912), 26; Gerd Korman, "Ethnic Democracy and Its Ambiguities: The Case of the Needle Trade Unions," American Jewish History, Vol. 75, No. 2 (June, 1986), pp. 405-426.

79. David H. Hirsch, The Destruction of Literature: Criticism after Auschwitz (Providence, 1991), pp. 157-165; Saul Friedlander, "Introduction," Vincent. P. Precora, "Habermas, Enlightenment and Anti-Semitism," and Sande Cohen, "Between Image and Phrase: Progressive History and the 'Final Solution' and Disposession," in Probing the Limits of Representation, ed. Friedlander (Cambridge, 1992), pp. 13-14, 155-184. See also George L. Mosse, "Die Deutsche Rechte und die Juden," Entscheidungsyahr 1932 (New York, 1966), p. 242; Friedlander, Nazi Germany and the Jews (New York, 1997), pp. 73-112 and Henry Feingold, A Time for Searching (Baltimore, 1992), pp. 226, 250-259. 